DOI: 10.1002/adsc.201501024

\title{
Non-Heme Imine-Based Iron Complexes as Catalysts for Oxidative Processes
}

\author{
Giorgio Olivo, ${ }^{\mathrm{a}, \mathrm{b}}$ Osvaldo Lanzalunga, ${ }^{\mathrm{a}, \mathrm{b}}$ and Stefano Di Stefano ${ }^{\mathrm{a}, \mathrm{b}, *}$ \\ a Dipartimento di Chimica, Università degli Studi di Roma "La Sapienza" and Istituto CNR di Metodologie Chimiche \\ (IMC-CNR), Sezione Meccanismi di Reazione, c/o Dipartimento di Chimica, Università degli Studi di Roma "La \\ Sapienza", P. le A. Moro 5, 00185 Rome, Italy \\ E-mail: stefano.distefano@uniroma1.it \\ b CIRCC Interuniversity Consortium of Chemical Catalysis and Reactivity, Via Celso Ulpiani 27, 70126 Bari, Italy
}

Received: November 6, 2015; Revised: December 11, 2015; Published online: February 17, 2016

\begin{abstract}
Non-heme iron complexes are emerging as powerful and versatile catalysts in several oxidative transformations. The most investigated iron complex structures are based on aminopyridine ligands, but a number of imine-based ligands have been also tested. In this review a collection of recent results obtained in oxidation catalysis with non-heme iminebased iron complexes is presented. Their catalytic performances in $\mathrm{C}-\mathrm{H}, \mathrm{C}=\mathrm{C}$ and $-\mathrm{S}-$ oxidation are spread over a wide range of efficiency, going from very low to quite high. Such performances are discussed, whenever possible, in light of the operating reaction mechanisms and of catalyst stability. In order to facilitate the discussion, an initial survey of the most useful mechanistic tools widely applied to distinguish a metal-based oxidation from a radicalchain process is also reported. Imine-based catalysts are divided into two classes: (i) salen-Fe complexes, and (ii) imine-Fe complexes. In some cases clues for free-radical oxidation mechanisms have been reported while in other cases evidence for metal-based mechanisms has been collected. The preferred mechanistic pathway is shown to be a function of catalyst structure and features. Interestingly, some iminebased iron complexes are able to perform stereospe-
\end{abstract}

cific oxidation reactions, demonstrating that the imine functionality can be incorporated in ligands designed for oxidation catalysis.

1 Introduction

2 Tools to Distinguish between Metal-Based and Free-Radical Oxidation Mechanisms

2.1 Alcohol/Ketone Ratio (A/K)

2.2 Kinetic Isotope Effects (KIE)

2.3 Reaction under Argon/Air

2.4 Shul'pin Test for Alkyl Hydroperoxides

2.5 Regioselectivity

2.6 Epimerization

2.7 Chirality Transfer

2.8 Labeling Studies

2.9 Use of Radical Traps

2.10 Cyclohexene Oxidation

3 Imine-Based Iron Complexes as Catalysts for Oxidation Reactions

3.1 Salen-Based Iron Catalysts

3.2 Other Imine-Based Iron Complexes

4 Conclusions

Keywords: autoxidation; iron; oxidation; reaction mechanisms; Schiff bases

\section{Introduction}

Selective oxidation of non-activated $\mathrm{C}-\mathrm{H}$ bonds is one of the longstanding goals in organic synthesis. ${ }^{[1-3]}$ Direct functionalization of aliphatic $\mathrm{C}-\mathrm{H}$ bonds represents an ideal transformation, as it allows the direct incorporation of the desired function into the target molecule, eliminating the need of preinstalled functional groups. ${ }^{[4,5]}$ Such a strategy largely minimizes chemical waste production. In particular, a clean and efficient late stage $\mathrm{C}-\mathrm{H}$ functionalization would avoid the unproductive manipulations necessary for interconverting, protecting and deprotecting functional groups throughout the synthetic sequence. Also other oxidative processes, such as olefin epoxidation and sulfide oxidation, have received considerable attention for the relevance of epoxides and sulfoxides in synthetic organic procedures. ${ }^{[6-10]}$ Although several methods for the preparation of such functionalities have already been developed, the quest for more general catalytic systems which use more abundant and sustainable reagents is still ongoing.

In the field of $\mathrm{C}-\mathrm{H}$ oxidations, great advances were accomplished in recent years by the use of bioinspired non-heme aminopyridine iron complexes $/ \mathrm{H}_{2} \mathrm{O}_{2}$ catalytic systems. ${ }^{[11-23]}$ These complexes proved to be also 
Giorgio Olivo obtained a master degree in chemistry at La Sapienza University of Rome in 2012. He is currently finishing his $\mathrm{PhD}$ in the group of Dr. S. Di Stefano at the same institution. His research interests focus on the study and development of iron and manganese coordination complexes as catalysts for $\mathrm{C}-\mathrm{H}$ oxidation reactions.

Osvaldo Lanzalunga received his $\mathrm{PhD}$ in chemical science in 1994 at the University of Rome La Sapienza. He was postdoctoral fellow with Prof. S. Steenken at the Max Planck Institut für Strahlenchemie in Mülheim. He was appointed Researcher (1996) and then Associate Professor (2005) at the University of Rome La Sapienza. His research interests include electron transfer and radical reactions, and the mechanism of enzymatic and biomimetic oxidation of organic substrates.
Stefano Di Stefano received his $\mathrm{PhD}$ in chemical science in 2000 at the University of Rome La Sapienza. After a period in the pharmaceutical industry, he came back to the same university where has held a permanent position since 2007. His research interests are focused on the field of

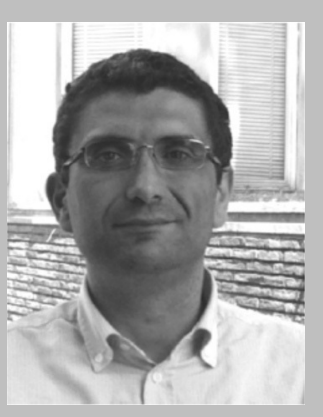
supramolecular chemistry and catalysis. He is a lecturer of physical organic chemistry and reaction mechanisms at La Sapienza. excellent catalysts for epoxidation ${ }^{[24-31]}$ or cis-dihydroxylation $^{[32-38]}$ of olefins.

Such catalysts offer several advantages when compared to the currently used catalytic systems: (i) the abundant, cheap and environmentally friendly iron and $\mathrm{H}_{2} \mathrm{O}_{2}$ are used as the metal center and the terminal oxidant, respectively, (ii) a selective, metal-based oxidation mechanism devoid of free diffusing radical formation is mostly operating, ${ }^{[13,39-42]}$ which ensures a good degree of selectivity by manipulation of the catalyst structure, ${ }^{[14,17,43]}$ (iii) in many cases, synthesis of non-heme amine-based iron complexes is significantly less demanding than that of metalloporphyrin heme model complexes. ${ }^{[44-47]}$

The development of non-heme amine-based iron catalysts has been accompanied over the years by a parallel study of non-heme imine-based iron counterparts, although the latter received less interest probably due to the conviction that imines (or Schiff bases) are not robust enough to be conveniently employed in typical oxidation conditions. Yet, some imine-based complexes proved to be stable enough to serve as oxidation catalysts (vide infra). Moreover, imine ligands are even easier to synthesize than the corresponding amines ${ }^{[48-50]}$ and this represents a significant advantage in catalyst design and preparation. The aim of this review article is to describe the state of art in non-heme imine-based iron catalysts for C$\mathrm{H}, \mathrm{C}=\mathrm{C}$ and $\mathrm{S}$ oxidation. Contributions reported by several research groups and our own contribution to the topic will be described in the following sections.

The mechanistic analysis of the oxidation reactions promoted by non-heme iron complexes has received a considerable amount of attention in recent years. ${ }^{[39,42,51,52]}$ The selective metal-based oxidative pathway often competes with a rather unselective radical chain autoxidation process initiated by oxygencentered radicals produced in Fenton-type reactions between iron ions and peroxides ${ }^{[33]}$ (Scheme 1). Such autoxidation processes suffer all the intrinsic limitations on selectivity and, above all, predictability always associated with highly energetic radical processes. Competition between the metal-based and the free-radical oxidation processes is dependent on reaction conditions, catalyst structure and oxidant employed.

In contrast with what is observed in the oxidations promoted by non-heme amine-based iron complexes which commonly proceed via a metal-based mechanism (Scheme 1), ${ }^{[13,39]}$ a high level of variability and/or uncertainty between a free-radical and a metal-based mechanism is found for non-heme imine-based ironcatalyzed oxidations. Elucidation of the oxidation pathway is of paramount importance since the selectivity properties and the possible synthetic applications of the catalytic system strongly depend on its mechanism of action. For this reason we feel that an initial discussion on the main mechanistic tools used 

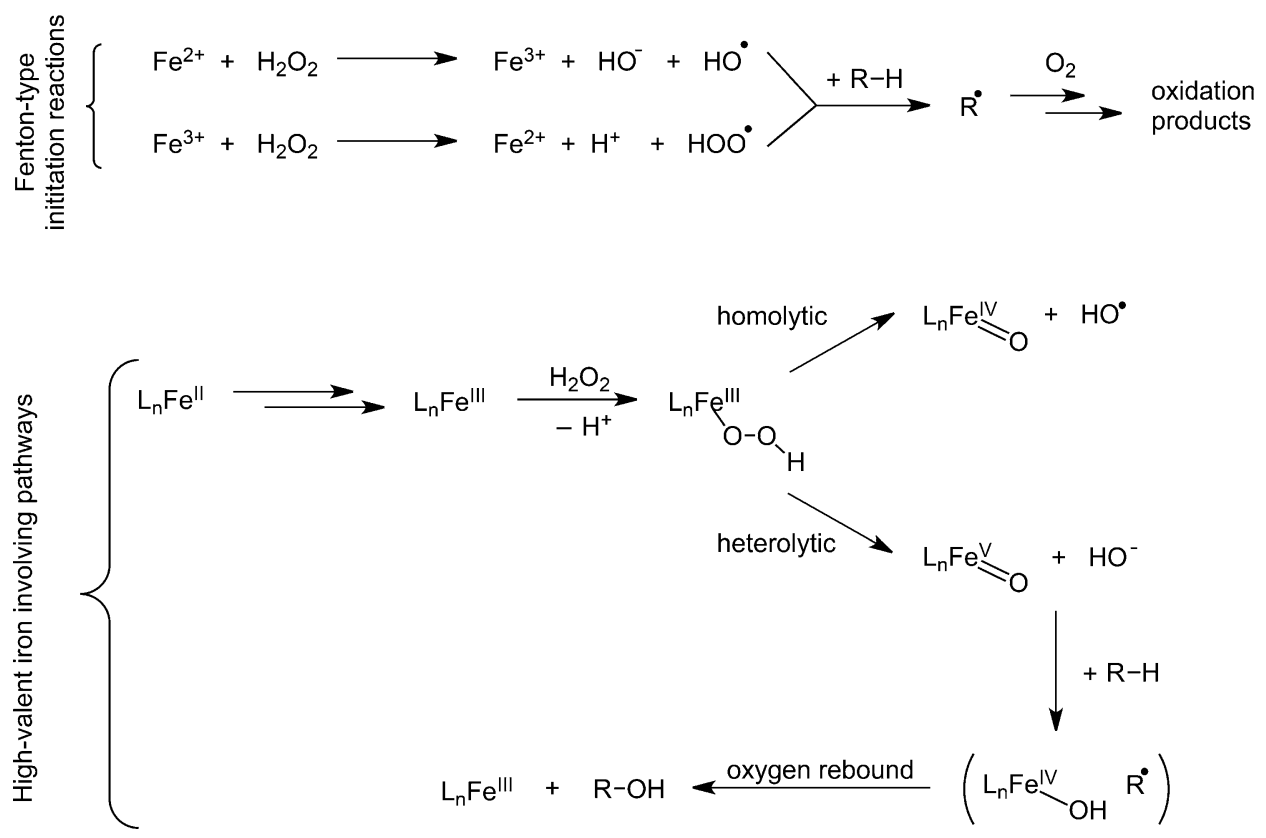

Scheme 1. Free-radical and metal-based oxidation pathways.

to discriminate between a metal-based and a free-radical mechanism is of definite interest for the subsequent sections.

\section{Tools to Distinguish between Metal-Based and Free-Radical Oxidation Mechanisms}

The highly reactive oxygen-centered radicals generated during a free-radical oxidation pathway are poorly selective oxidants, unable to discriminate between $\mathrm{C}-$ $\mathrm{H}$ bonds of different strengths. Furthermore, the alkyl radicals formed after the hydrogen transfer process may lead to a variety of oxidation products as a consequence of their rearrangement, epimerization and reaction with $\mathrm{O}_{2} \cdot{ }^{[54]}$ On the other hand, metal-based oxidants are more selective producing carbon-centered radicals which are usually unable to rearrange or epimerize before the very rapid oxygen rebound (in $\mathrm{C}-$ $\mathrm{H}$ oxidation) (Scheme 1 ). In $\mathrm{C}=\mathrm{C}$ and $\mathrm{S}$ oxidation, direct $\mathrm{O}$-atom transfer is usually operating for metalbased iron-oxo species, ${ }^{[39,55-58]}$ allowing the achievement of enantioselective oxidations in the presence of chiral ligands. ${ }^{[13,24,59,60]}$ On the contrary racemic epoxides or sulfoxides are expected in the case of an involvement of radical oxidative pathways.

A series of mechanistic probes used to distinguish whether an iron-mediated oxidation follows a metalbased or a free-radical mechanism is reported in this section. ${ }^{[61]}$ None of the following clues can be considered on its own a definitive proof in favor of one mechanism. On the other side, if most of them point to one of the two dichotomous pathways, this one will be accepted.

\subsection{Alcohol/Ketone Ratio (A/K)}

The $\mathrm{A} / \mathrm{K}$ product ratio is a simple yet powerful test for radical-based oxidations. ${ }^{[61,62]}$ This test is performed under air, with a large excess of substrate (usually cyclohexane or cyclooctane, see Scheme 2) with respect to the oxidant (10:1 or 100:1).

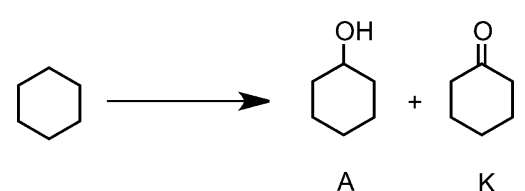

Scheme 2. Oxidation of cyclohexane to cyclohexanol (A) and cyclohexanone $(\mathrm{K})$.

Freely diffusing alkyl radicals are rapidly trapped by $\mathrm{O}_{2}$ yielding alkylperoxyl radicals. Russell-type terminations of such intermediates form equimolar amounts of alcohol and ketone, irrespective of the substrate/oxidant ratio (Scheme 3$) .^{[62,63]} \mathrm{A} / \mathrm{K}$ ratios close to or lower than 1 obtained in such conditions are usually indicative of a radical chain oxidation mechanism. ${ }^{[13,62]}$ On the other hand, in metal-based reactions, oxygen rebound (see Scheme 1) should be faster than $\mathrm{O}_{2}$ trapping of the incipient radical. ${ }^{[62,64-66]}$ In this case, the alcohol is the major oxidation prod- 


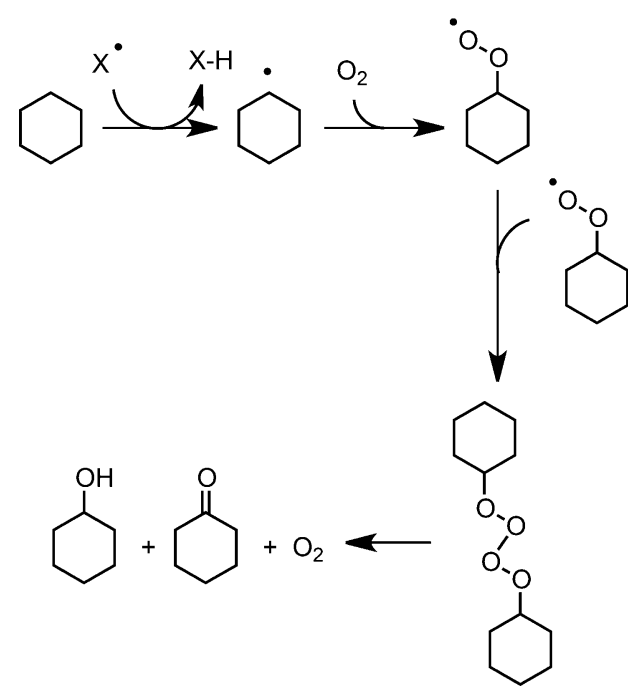

Scheme 3. Radical chain cyclohexane oxidation and Russell termination mechanism.

uct accompanied by minor amounts of ketone generated by its over-oxidation $(\mathrm{A} / \mathrm{K}>5) .{ }^{[13,62,65]}$ Furthermore, in metal-based oxidations, if the product distribution is followed over time, the $\mathrm{A} / \mathrm{K}$ ratio should be very high at the beginning of the reaction (the alcohol is the first generation product), and then decrease over time.

\subsection{Kinetic Isotope Effects (KIE)}

The intermolecular kinetic isotope effect is usually determined in a competitive oxidation of a hydrocarbon (usually cyclohexane, $\mathrm{C}_{6} \mathrm{H}_{12}$ ) and its deuterated counterpart $\left(\mathrm{C}_{6} \mathrm{D}_{12}\right.$, see Scheme 4$)$.

Highly reactive oxygen-centered radicals are not able to discriminate between $\mathrm{C}-\mathrm{H}$ and $\mathrm{C}-\mathrm{D}$ bonds, yielding KIE values in the range $1-2 .{ }^{[67]}$ Higher KIE values, from about 3 up to 4-5, have been measured for selective, metal-based oxidants. ${ }^{[13,41,51,61,68,69]}$ Values higher than the theoretical maximum (ca. 7) have been determined in some cases and rationalized on the basis of the contribution of tunneling effects. It has to be remarked that KIE analysis gives information only on the selectivity determining step as recently pointed out by Hartwig. ${ }^{[70]}$

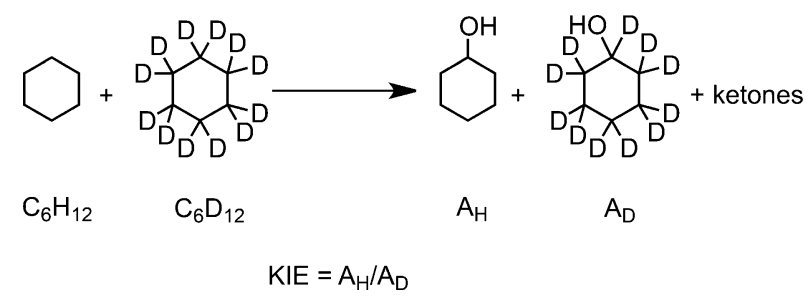

Scheme 4. Oxidation of cyclohexane and cyclohexane- $d_{12}$ to determine KIE.

\subsection{Reaction under Argon/Air}

As previously described carbon-centered radicals are commonly trapped by $\mathrm{O}_{2}$ at diffusion controlled rates leading to final oxidation products alcohols and ketones. If a free-radical mechanism is operating, careful exclusion of $\mathrm{O}_{2}$ from the reaction mixture (all reagents and solvents purged) is expected to significantly lower the oxidation yields. Conversely, if the mechanism is metal-based, comparable results should be observed regardless of the presence or absence of molecular oxygen. This test has been very informative in several cases, ${ }^{[71,72]}$ but interpretation of the results deserves some caution. Iron complexes, like those of other first-row transition metals, display a catalaselike activity on peroxides producing $\mathrm{O}_{2}$. In the latter case, the in-situ formed $\mathrm{O}_{2}$ may provide the same results for the reaction carried out under air or under argon, and give a false positive response to this test. To solve this problem, low amounts of oxidant can be used (i.e., 1-10 molar equivalents with respect to the catalyst $)^{[59]}$ or a continuous oxygen purging system can be kept operating throughout the reaction. ${ }^{[62,71]}$

\subsection{Shul'pin Test for Alkyl Hydroperoxides}

This method represents a simple way to detect the formation of alkyl hydroperoxides (e.g., cyclohexyl hydroperoxide) in oxidation reactions. Alkyl hydroperoxide by-products are typical clues of radical chain oxidations, and are formed by hydrogen atom abstraction from solvent or substrate molecules by alkyl peroxyl radicals. Direct detection of such species may be not trivial since they may decompose into alcohols and ketones during the GC analysis. In the test elaborated by Shul'pin and co-workers, ${ }^{[7-75]} \mathrm{Ph}_{3} \mathrm{P}$ is added to the final reaction mixture and it readily and quantitatively reduces the alkyl hydroperoxide to the corresponding alcohol (Scheme 5). If the GC analysis performed before and after the addition of $\mathrm{Ph}_{3} \mathrm{P}$ reveals an increased amount of alcohol, alkyl hydroperoxides are likely formed under reaction conditions by a free radical chain oxidation.

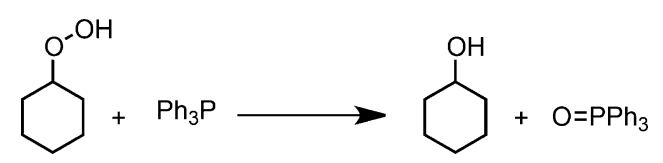

Scheme 5. Cyclohexyl hydroperoxide reduction by $\mathrm{Ph}_{3} \mathrm{P}$ used in the Shul'pin test.

\subsection{Regioselectivity}

The analysis of the ratios among tertiary:secondary: primary $\mathrm{C}-\mathrm{H}$ bond oxidation (i.e., the selectivity in 


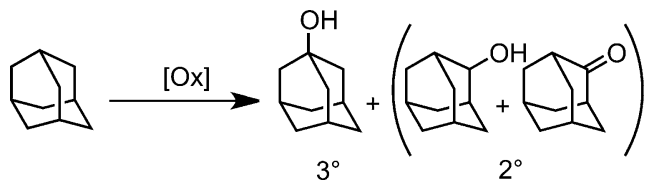

Scheme 6. Adamantane oxidation to determine the tertiary to secondary ratio.

hydrogen transfer processes) may provide useful information on the nature of the hydrogen abstracting species. ${ }^{[6176]}$ For example, in adamantane oxidation the ratio of tertiary over secondary $\mathrm{C}-\mathrm{H}$ bond oxidation products $\left(3^{\circ} / 2^{\circ}\right.$ ratio, normalized for statistical factors, see Scheme 6), is rather low with very reactive hydroxyl and alkoxyl radicals. ${ }^{[77]}$ On the other hand, for the active species of cytochrome P450 enzymes and other selective heme catalysts, the adamantane regioselectivity can achieve values as high as $48 .^{[42,68]}$ Thus, while low values of the tertiary to secondary ratio $\left(3^{\circ} / 2^{\circ}<6\right)$ are indicative of a free-radical mechanism, $3^{\circ} / 2^{\circ}$ ratios higher than $13-15$ strongly point to a metal-based mechanism.

\subsection{Epimerization}

Formation of alkyl radicals may lead to a loss of stereochemical information by rapid inversions of configuration at the radical center. When such a rearrangement has a rate comparable to or faster than the oxygen rebound step, significant epimerization is observed in the products. ${ }^{[13]}$ One of the most effective tests concerns retention of configuration or epimerization in cis-1,2-dimethylcyclohexane oxidation (Scheme 7). The tertiary carbon radical epimerizes with an estimated $k$ of $\sim 10^{9} \mathrm{~s}^{-1} \cdot{ }^{[78]}$ Oxidations generating radicals with a lifetime higher than $\sim 10^{-9} \mathrm{~s}$ exhibit low retention of configuration (a cis:trans ratio of approximately 1.2 has been reported for hydroxyl radical) ${ }^{[79]}$ On the other hand, metal-based oxidations afford high retention of configuration (90-99\%). A similar test can be carried out also on cis-decaline, which undergoes epimerization at a rate comparable with that of cis-1,2-dimethylcyclohexane.

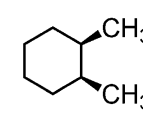

cis-DMCH

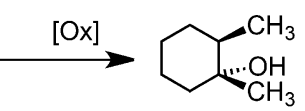

cis- $\mathrm{OH}$

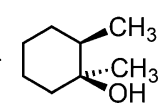

trans-OH
Scheme 7.1,2-cis-Dimethylcyclohexane (cis-DMCH) oxidation to determine the retention of configuration ( $\mathrm{RC}) . \mathrm{RC}$ is defined as $100 \times($ cis- $\mathrm{OH}-$ trans-OH $) /($ cis- $\mathrm{OH}+$ trans-OH $)$.

\subsection{Chirality Transfer}

In metal-based oxidations promoted by chiral catalysts a chirality transfer from the catalyst to the substrate may occur as found in the oxidation of several unsymmetrical olefins or sulfides. ${ }^{[13,24,59]}$ Contrarily, chirality transfer cannot be observed when the oxidation processes are promoted by achiral oxygen-centered radicals.

\subsection{Labeling Studies}

Isotope labeling studies have been used to distinguish oxidation mechanisms mediated by metal-oxo species from free radical species. ${ }^{[13]}$ As already stated, atmospheric $\mathrm{O}_{2}$ incorporation into products indicates the formation of not-caged, long-lived alkyl radicals along the reaction pathway. On the other hand, if the Oatom comes from the peroxide or water (vide infra), a metal-based oxidation should be involved. ${ }^{[13,46,80]}$ Since high-valent metal-oxo species may undergo rapid oxo-hydroxo tautomerism prior to the oxidation step (Scheme 8), the reactive oxo ligand transferred

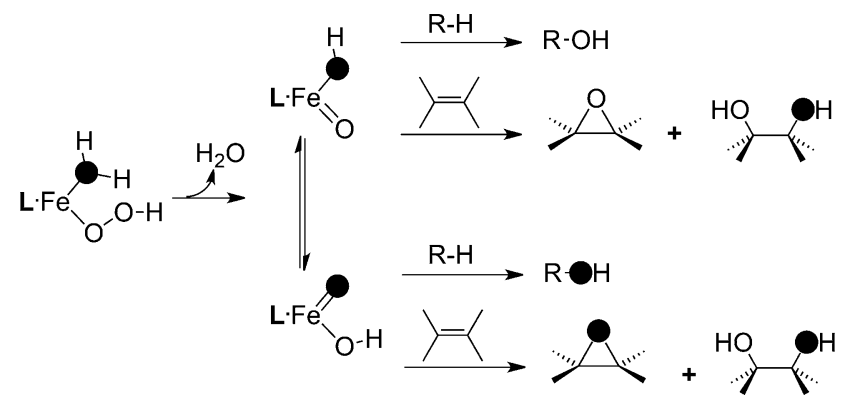

Scheme 8. Oxo-hydroxo tautomerism.

to the substrate may derive from a water ligand. ${ }^{[13,18,37,80]}$ In fact, since neither $\mathrm{H}_{2} \mathrm{O}_{2}$ nor the $\mathrm{Fe}-\mathrm{OOH}$ intermediate can exchange their oxygen atom with water, O-atom incorporation from $\mathrm{H}_{2} \mathrm{O}$ constitutes an indirect evidence for the involvement of an iron-oxo moiety. ${ }^{[80]}$ The origin of the $\mathrm{O}$-atom in the oxidation products can be elucidated by use of $\mathrm{H}_{2}{ }^{18} \mathrm{O}$ and, subsequently, $\mathrm{H}_{2}{ }^{18} \mathrm{O}_{2}$. When the oxidation is carried out in the presence of $\mathrm{H}_{2}{ }^{18} \mathrm{O}$ and $\mathrm{H}_{2} \mathrm{O}_{2}$ a certain percentage of labeled oxygenated product will be obtained. If the same experiment is carried out with $\mathrm{H}_{2} \mathrm{O}$ and $\mathrm{H}_{2}{ }^{18} \mathrm{O}_{2}$ and the complementary percentage of labeled oxygenated product is observed, a genuine metal-based mechanism is operating. Any decrease of the sum of the above percentages from $100 \%$ weights the contribution of a radical autoxidation pathway. 


\subsection{Use of Radical Traps}

Another tool to check the involvement of free radical intermediates in a reaction is the use of radical traps. If a compound able to react very rapidly with radicals significantly affects reaction outcomes, a free-radical mechanism is very likely operating. However, caution should be taken when radical traps are used in the presence of metal complexes since a direct interaction of the radical trap with the catalyst may occur and interfere with the experimental results. In this respect $\mathrm{CBrCl}_{3}$ represents a suitable radical scavenger able to trap not-caged carbon-centered radicals at diffusion controlled rates leading to alkyl bromides (Scheme 9). This species does not interfere with the metal complex when used at low concentrations (i.e., 1/10 of the substrate). ${ }^{[62]}$ Other radical scavengers, such as $\mathrm{Ph}_{2} \mathrm{NH}$ and, mostly, DMPO (5,5-dimethylpyrrolidine $\mathrm{N}$ oxide), have been employed to trap oxygen-centered radicals.

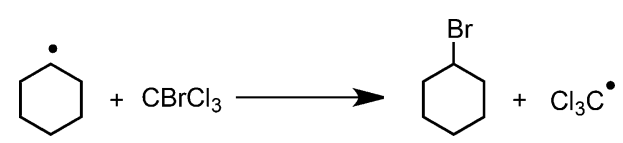

Scheme 9. Carbon-centered radical trapped by $\mathrm{CBrCl}_{3}$.

The use of radical traps in combination with EPR spectroscopy is also a useful mechanistic tool to detect the formation of free-diffusing radicals in the reaction mixtures. ${ }^{[81]}$ According to the protocol developed by Beller et al. ${ }^{[82]}$ trace amounts of the desired radical trap are added to the reaction mixture under catalytic conditions. The solution is rapidly freezequenched at $77 \mathrm{~K}$ and analyzed by EPR spectroscopy.

\subsection{Cyclohexene Oxidation}

An additional useful tool in the study of oxidation mechanism is the analysis of cyclohexene oxidation products. ${ }^{[83]}$ Unlike other cyclic olefins (such as cyclooctene), cyclohexene has a marked tendency to undergo allylic hydrogen atom abstraction in the presence of free radicals (see Scheme 10). For this reason, free radical-promoted oxidations generally yield allylic alcohols or unsaturated ketones, while metal-based oxidants usually give the epoxides by oxygen atom transfer ${ }^{[83]}$ However, the results of this test should be

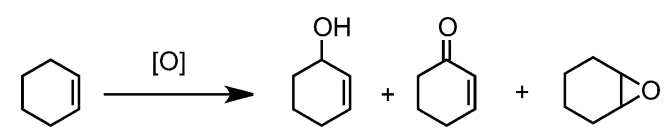

Scheme 10. Products formed in the oxidation of cyclohexene. always cross-checked with the ones of other tests, since even catalytic systems which usually operate through a metal-based mechanism may give a certain amount of allylic oxidation products. ${ }^{[84]}$

\section{Imine-Based Iron Complexes as Catalysts for Oxidation Reactions}

As stated in the introduction, imines are generally easier to prepare than the corresponding amines since they can be obtained by the simple addition in solution of the parent carbonyl compound and the primary amine in appropriate molar ratios and solvents. ${ }^{[48,49]}$ Furthermore, a metal cation such as Fe(II) or $\mathrm{Fe}(\mathrm{III})$ can act as a template for imine bond formation with the consequent in-situ generation of the complex. ${ }^{[85]}$ Despite this significant advantage, imines are far less investigated ligands than amines in iron oxidation catalysis. This fact is probably due to the lower stability of the imine bond when compared with the amine bond, as the former is susceptible to hydrolysis. ${ }^{[86]}$ Hydrolytic processes can be accelerated by the Lewis acidic character of the metal center, leading to rapid ligand degradation and consequent release of the iron cation in solution. This is a crucial point, since the free iron salt or, more generally, complexes with more than two labile sites on the iron ion usually favor Fenton-type oxidation, ${ }^{[87,88]}$ with all the problems related to free radical generating chemistry. Moreover, one of the main degradation pathways proposed for non-heme $\mathrm{Fe}(\mathrm{II})$ and $\mathrm{Mn}(\mathrm{II})$ catalysts consists in the oxidation of ligand aminic $\mathrm{C}-\mathrm{N}$ bonds and subsequent hydrolysis of the resulting imine. ${ }^{[88,89]}$

Notwithstanding, imine-based iron complexes have been successfully employed as oxidation catalysts. Here follows a summary of iron systems which have been studied by several research groups, as catalysts in oxidation reactions.

\subsection{Salen-Based Iron Catalysts}

Most of the time, the key to overcome the imine ligand degradation (hydrolysis) has been the formation of highly stable polydentate complexes. For instance, this strategy has been adopted in the preparation of salen-type complexes (Figure 1), which are very stable under catalytic conditions, even reaching 500 TONs in oxidation reactions. ${ }^{[90]}$

Salen ligands $\left(\mathrm{N}_{2} \mathrm{O}_{2}\right.$ type ligands), doubly negatively charged, are robust ligand platforms, and have the advantage of being easily tunable. ${ }^{[91]}$ Stereogenic centers can be introduced on the diamine backbone, close to the metal center, enabling chirality transfer (see Figure 1). ${ }^{[90,92,93]}$ Moreover, electronic and steric 

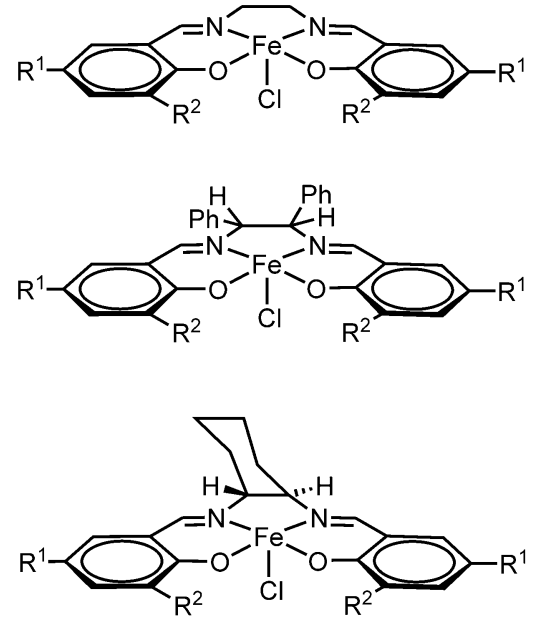

Figure 1. $[($ Salen $) \mathrm{Fe}(\mathrm{Cl})]$ complexes employed in oxidation reactions.

properties of the ligand can be manipulated by varying substituents in para or ortho positions of the phenolic rings respectively (substituents $\mathrm{R}^{1}$ and $\mathrm{R}^{2}$ depicted in Figure 1). ${ }^{[55,90,92,94,95]}$ Salen-Mn and salen-Cr complexes have shown very high catalytic efficiencies in olefin epoxidation, ${ }^{[91,95]}$ therefore the opportunity to replicate such catalytic performances with more convenient salen-Fe complexes seemed straightforward. Unfortunately, salen-iron complexes have been found to be less active oxidation catalysts than their $\mathrm{Mn}$ or $\mathrm{Cr}$ analogues. ${ }^{[85,91,96]}$

Salen-Fe(III) complexes found the main application in the oxidation of reactive functional groups, and particularly in sulfide oxidation. ${ }^{[85]} \mathrm{A}$ chiral diamine backbone (1,2-trans-diaminocyclohexane, see Figure 1) allowed the realization of moderate-to-good yields and enantiomeric excesses up to $84 \%$ with iodosobenzene (PhIO) as the oxidant. ${ }^{[00]}$ Acetonitrile used as the solvent was found to maximize both the catalytic activity and the enantioselectivity. The enantiomeric excesses were sensitive to the chiral diamine used (1,2-trans-diaminocyclohexane was the best-performing one), to phenolic ring substituents $(t$-Bu in ortho and para positions were the optimal ones), to the steric hindrance of the sulfide $\left[\mathrm{Ar}-\mathrm{S}-\mathrm{CH}\left(\mathrm{CH}_{3}\right)_{2}\right.$ gave the highest $e e]$ and to the nature of the terminal oxidant employed. ${ }^{[00,92]} m$-Chloroperbenzoic acid (mCPBA), ${ }^{[00,94,97]} \mathrm{NaOCl},{ }^{[98]} \mathrm{H}_{2} \mathrm{O}_{2}{ }^{[99]}$ or $\mathrm{H}_{2} \mathrm{O}_{2}$-urea ${ }^{[100]}$ gave generally lower results than iodosobenzene. ${ }^{[94,96,99-101]}$ A different strategy was recently explored by List and Liao. They used an achiral saleniron catalyst with a chiral counteranion (the conjugated base of an axially enantioenriched binaphthyl-derived phosphoric acid) to generate an ion pair able to efficiently oxidize sulfides to sulfoxides with good-toexcellent yields and enantiomeric excesses up to $99 \%$, using PhIO as the oxidant. ${ }^{[102]}$ The incorporation of the salen-Fe catalyst into a metal organic framework (MOF) was demonstrated to be another effective strategy to achieve highly stereoselective sulfide oxidations with $\mathrm{PhIO}$ as the oxidant (up to $96 \%$ ee). ${ }^{[101]}$ An increase of the topicity of the ligand to generate a "triple-salen" complex afforded comparable yields but lower enantioselectivity than the simple monomeric salen-Fe(III) complex. ${ }^{[103]}$

The mechanism of sulfide oxidation mediated by salen-Fe(III) complexes has attracted considerable attention over the years, and a lively debate ensued on the nature of the oxidizing species. On the basis of UV-Vis, EPR and resonance Raman analysis, in $2002^{[94]}$ Rajagopal and co-workers proposed an electrophilic $\left(\right.$ salen $\left.^{+\cdot}\right) \mathrm{Fe}(\mathrm{IV})(\mathrm{O})(\mathrm{X})$ intermediate (see Figure 2), kinetically competent for sulfide oxidation, formed by $\mathrm{O}$-atom transfer from $\mathrm{PhIO}$ or $\mathrm{O}-\mathrm{O}$ heterolysis from $m$ CPBA. This species exhibited a Michaelis-Menten saturation behavior, indicating prior coordination of the sulfide substrate to the oxidizing species. ${ }^{[94,99]}$ However, a few years later, Bryliakov and Talsi ${ }^{[00]}$ challenged such an assignment, providing strong evidence for a (salen)Fe(III)( $\mathrm{PhIO})(\mathrm{X})$ species (see Figure 2) as the active oxidant with PhIO by ${ }^{1} \mathrm{H}$ NMR and EPR spectroscopy. No products were formed when $m$ CPBA was used.

In 2005 Fujii and co-workers ${ }^{[97]}$ carried out a thorough study on the formation and characterization of salen-Fe intermediates in oxidative conditions. A bulky salen-Fe(III) complex was electrochemically oxidized, and two oxidation waves at 0.85 and $0.96 \mathrm{~V}$ vs. $\mathrm{Fc} / \mathrm{Fc}^{+}$were detected. The products obtained by
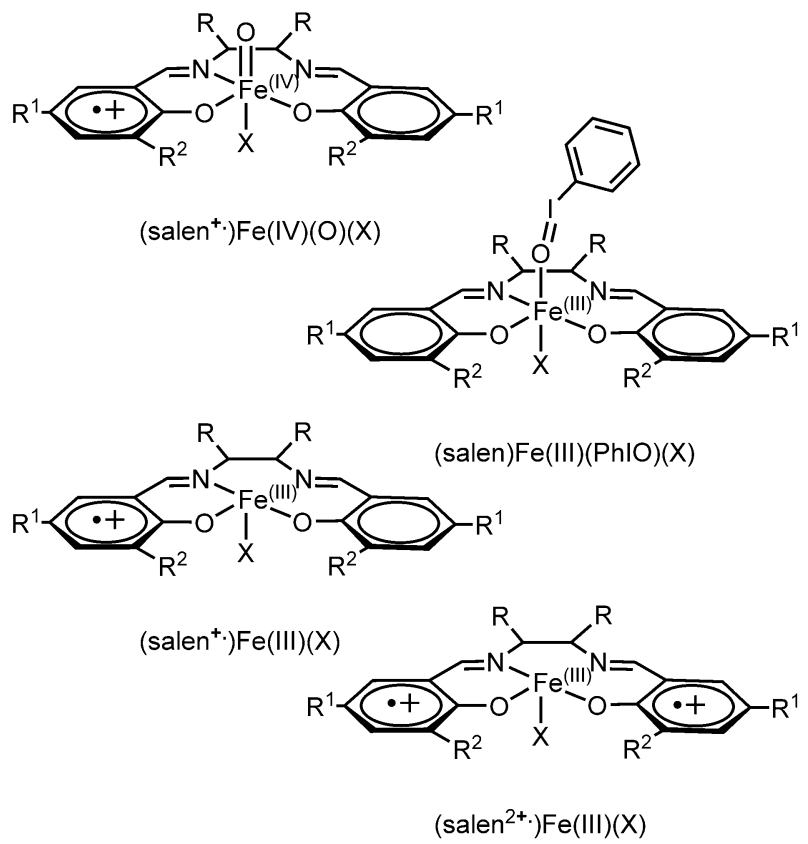

Figure 2. Proposed intermediates competent for the oxidation step in the salen-Fe complexes with different oxidants. 
electrochemical oxidation were identified as the mono- and di-radical cation salen-Fe(III) complexes, respectively, on the basis of UV-Vis, resonance Raman, Mossbauer, EPR and ESI-MS characterization. One or two oxidation equivalents are hosted on the phenoxy rings, while the metal center retains its Fe(III) oxidation state (see Figure 2). In the presence of $m \mathrm{CPBA}$, only the mono-oxidized Fe(III) phenoxy radical was observed, and this species was found to be a sluggish oxidant, unable to oxidize benzyl alcohols or cyclohexene, in line with Bryliakov's report. ${ }^{[0]}$ These results indicated a high stabilization of the iron(III) oxidation state by the salen ligand, suggesting that higher iron oxidation states are not accessible. The impossibility to access $\mathrm{Fe}(\mathrm{IV})$ or $\mathrm{Fe}(\mathrm{V})$ oxidation states was proposed to account for the lack of high oxidative activity exhibited by salen-Fe complexes. In 2007 Bryliakov and Talsi ${ }^{[92]}$ found that the enantiomeric excesses in sulfide oxidations were sensitive to ArIO substituents. In particular the ee increased with the increase of steric hindrance on the aryl ring. These results implied that the ArIO oxidant must be coordinated to the oxygen-transferring species, and strongly supported its formulation as the salen-Fe(III)(ArIO)(X) intermediate previously proposed. ${ }^{[90]}$ The fifth ligand on the iron complex (i.e., the one trans to the position occupied by the oxidant) exerted some influence on the catalytic activity, with neutral strongly coordinating ligands (such as pyridine or 1-methylimidazole) usually giving the best results. ${ }^{\left[{ }^{[2]}\right.}$ Later, some reports indicated that the oxidizing intermediate formed with $\mathrm{H}_{2} \mathrm{O}_{2}$ as the oxidant might be a high-valent $\left(\right.$ salen $\left.^{+\cdot}\right) \mathrm{Fe}(\mathrm{IV})(\mathrm{O})(\mathrm{X})$ (see Figure 2) ${ }^{[99,104,105]}$ but conclusive evidence of its assignment has not been yet collected.

Olefin epoxidation catalyzed by salen-Fe(III) complexes is less efficient than sulfide oxidation, ${ }^{[98,106]}$ in terms of both yields and enantioselectivity. ${ }^{[107]}$ Significant competitive peroxide disproportionation leading to depletion of the oxidant was observed. ${ }^{[06]}$ Cyclooctene was converted to the corresponding epoxide, while in cyclohexene oxidation the main products were usually found to be the allylic alcohol and ketone. ${ }^{[98,108]}$ This selectivity pattern probably points to a dominant free radical oxidation pathway which erodes also the ee. When styrene derivatives were used as substrates, significant amounts of benzaldehyde were detected, generated by formal oxidative $\mathrm{C}=\mathrm{C}$ bond cleavage, with both a simple salen-Fe catalyst ${ }^{[106]}$ and an immobilized one. ${ }^{[109]}$

Kaizer reported the use of salen-Fe catalysts in the oxidation of amino acids to ethylene, $\mathrm{CO}_{2}$ and $\mathrm{HCN}^{[105]}$ mimicking the 1-aminocyclopropane-1-carboxylic acid $(\mathrm{ACCH})$ oxidase, a non-heme iron enzyme involved in the biosynthesis of the ethylene plant hormone. Salen-Fe complexes catalyze the conversion of a series of cyclic and acyclic amino acids

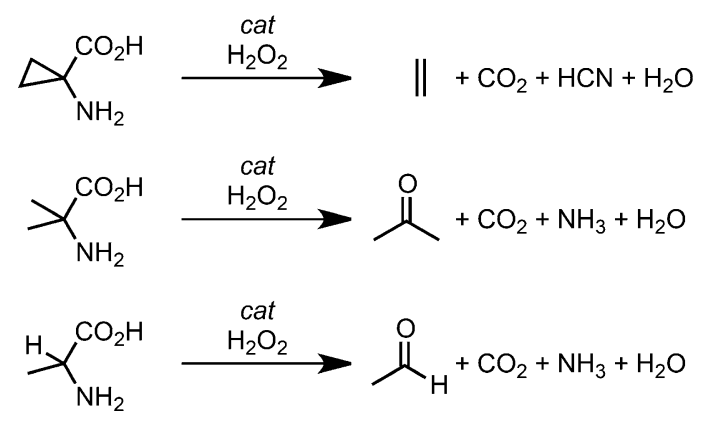

Scheme 11. Amino acid oxidation catalyzed by salen-Fe(X) complexes and $\mathrm{H}_{2} \mathrm{O}_{2}$.

into ethylene or a carbonyl compound, $\mathrm{NH}_{3}$ or $\mathrm{HCN}$ and $\mathrm{CO}_{2}$ by $\mathrm{H}_{2} \mathrm{O}_{2}$ (see Scheme 11) with a high efficiency (up to $90 \%$ ). The products formed depended on the amino acid structure. Other oxidants ( $m$ CPBA, $t$-BuOOH, PhIO) were also effective. ${ }^{[110]}$ Kinetic studies showed that the reaction is first order in oxidant and in catalyst, while a saturation behavior for the substrate was observed. It was attributed to initial coordination of the amino acid to the iron center. ${ }^{[105,110]}$ This initial step is followed by an electron transferproton transfer (ET-PT) process from the substrate to the iron-oxidant adduct, which triggers the subsequent rearrangements and fragmentations. ${ }^{[105,110]}$ The authors proposed a high valent $\left(\right.$ salen $\left.^{+\cdot}\right) \mathrm{Fe}(\mathrm{IV})=\mathrm{O}$ as the oxidizing species generated by reaction of the salen-Fe(III) complex with $\mathrm{H}_{2} \mathrm{O}_{2} \cdot{ }^{[105,110]}$

Oxidation of non-activated aliphatic $\mathrm{C}-\mathrm{H}$ bonds proved very challenging for salen-iron catalysts. Several studies reported relatively low conversions in cyclohexane oxidation with $\mathrm{H}_{2} \mathrm{O}_{2}$ or $t$ - $\mathrm{BuOOH}$ and selectivity patterns resembling those of Fenton-type reactions (roughly equimolar amounts of alcohol and ketone in cycloalkane oxidation).$^{[55,94,108,111,112]}$ As additional evidence for such a radical-chain oxidation mechanism, traces of chlorocyclohexane formed by oxidative ligand transfer from the (salen) $\mathrm{FeCl}$ catalyst to the substrate have been detected in the product mixture. ${ }^{[111,112]}$ Non-activated $\mathrm{C}-\mathrm{H}$ bond oxidation with $\mathrm{H}_{2} \mathrm{O}_{2}$ was demonstrated to require nitric acid as a co-catalyst. Different mineral or organic acids gave lower conversions. ${ }^{[13]}$ Electron-donating substituents in the para-position of the phenol ring exerted a beneficial effect in cyclohexane oxidation (see Figure 3 and Table 1). ${ }^{[13]}$ A TON as high as 97 was achieved in the more challenging $n$-hexane oxidation, but low selectivity has been observed. The related neutral $\mathrm{N}_{4}$ type iron complex $\left[\mathrm{Fe}(\right.$ pyhd $\left.)\left(\mathrm{Cl}_{2}\right)\right]$ (see Figure 3 ) gave lower yields in cyclohexane oxidation (see Table 1), indicating the essential role played by the two phenoxy moieties to stabilize the complex.

A different strategy is viable and consists in the use of the oxo-bridged dimer of a salen-Fe(III) complex as the catalyst. In 1980, Tabushi reported that a salen- 


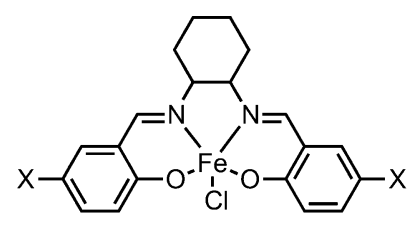

$\begin{array}{cl}\mathrm{X}=\mathrm{Br} & {[\mathrm{Fe}(\text { Brsalhd })(\mathrm{Cl})]} \\ \mathrm{H} & {[\mathrm{Fe}(\text { salhd })(\mathrm{Cl})]}\end{array}$

$\mathrm{Me} \quad[\mathrm{Fe}($ Mesalhd $)(\mathrm{Cl})]$

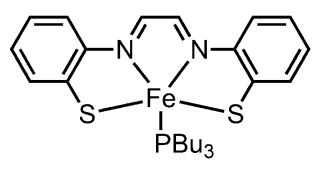

$\left[\mathrm{Fe}\left(\mathrm{gma}^{\bullet}\right)\left(\mathrm{Bu}_{3} \mathrm{P}\right)\right]$

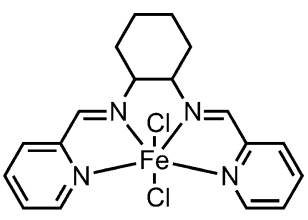

$\left[\mathrm{Fe}(\right.$ pyhd $\left.)(\mathrm{Cl})_{2}\right]$
Figure 3.

Table 1. Cyclohexane oxidation to cyclohexanol $(\mathrm{CyOH})$, cyclohexanone (CyO) and Cyclohexyl hydroperoxide $(\mathrm{CyOOH})$, mediated by iminopyridine iron complexes and

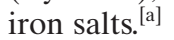

\begin{tabular}{|c|c|c|c|c|c|}
\hline \multirow[t]{2}{*}{ Entry } & \multirow[t]{2}{*}{ Catalyst } & \multicolumn{3}{|c|}{ Cyclohexane Oxidation } & \multirow[t]{2}{*}{ TON } \\
\hline & & $\mathrm{CyOH}$ & $\mathrm{CyO}$ & $\mathrm{CyOOH}$ & \\
\hline 1 & {$[(\mathrm{Brsalhd}) \mathrm{Fe}(\mathrm{Cl})]$} & 15 & 4 & $-^{[\mathrm{b}]}$ & 19 \\
\hline 2 & $[$ (salhd $) \mathrm{Fe}(\mathrm{Cl})]$ & 15 & 10 & $-^{[\mathrm{b}]}$ & 25 \\
\hline 3 & {$[$ (Mesalhd) $\mathrm{Fe}(\mathrm{Cl})]$} & 35 & 10 & $-^{[\mathrm{b}]}$ & 45 \\
\hline 4 & {$\left[(\right.$ pyhd $\left.) \mathrm{Fe}(\mathrm{Cl})_{2}\right]$} & 17 & 0.2 & $-^{[\mathrm{b}]}$ & 17 \\
\hline 5 & {$\left[\left(\mathrm{gma}^{\prime}\right) \mathrm{Fe}\left(\mathrm{Bu}_{3} \mathrm{P}\right)\right]^{[\mathrm{c}]}$} & 13 & 2 & $-^{[\mathrm{b}]}$ & 75 \\
\hline \multicolumn{6}{|c|}{$\begin{array}{l}\text { [a] Reaction conditions: catalyst: } \mathrm{H} \\
\text { 1:10:500:100, } \mathrm{CH}_{3} \mathrm{CN} \text {, air, } 25^{\circ} \mathrm{C}, 6 \mathrm{~h} \text {. }\end{array}$} \\
\hline \multicolumn{6}{|c|}{$\begin{array}{l}\text { [b] } \mathrm{CyOOH} \text { was detected, but } \mathrm{Ph}_{3} \mathrm{P} \text { addition prior to } \mathrm{GC} \\
\text { analysis quantitatively reduced it to } \mathrm{CyOH} \text {. }\end{array}$} \\
\hline
\end{tabular}

$\mathrm{Fe}(\mathrm{III}) \mu$-oxo dimer complex was found to perform preferential secondary over tertiary adamantane $\mathrm{C}-\mathrm{H}$ bond oxidation with $\mathrm{O}_{2}$ as the oxidant in the presence of a reducing agent (2-mercaptoethanol). ${ }^{[114]}$ In 2009 Palaniandavar and co-workers ${ }^{[112]}$ found that a dinulear $\mu$-oxo salen ${ }_{2}-\mathrm{Fe}_{2}$ (III) complex mediated efficient $\mathrm{C}-\mathrm{H}$ oxidations with $m \mathrm{CPBA}$ as the terminal oxidant (TONs in the range 6.5-30). An $\mathrm{A} / \mathrm{K}$ ratio of 12 was observed in cyclohexane oxidation, decreasing with reaction time. These results were consistent with a metal-based oxidation mechanism, and the authors proposed a salen- $\mathrm{Fe}(\mathrm{IV})(\mathrm{O})(\mu-\mathrm{O}) \mathrm{Fe}(\mathrm{IV})(\mathrm{O})$-salen to be the real oxidizing species. On the other hand, the mononuclear catalyst led to a low $\mathrm{A} / \mathrm{K}$ ratio (1.7), indicative of a radical process. $t$-Bu substituents were required in both the ortho- and para-positions of the phenoxy rings to prevent ligand oxidative degradation and therefore to display a good catalytic activity. Other oxidants $\left(\mathrm{H}_{2} \mathrm{O}_{2}\right.$ and $t$ - $\left.\mathrm{BuOOH}\right)$ were found to bind to the iron centers as ascertained by ESI-MS and UV-Vis analyses, but not to promote $\mathrm{C}-\mathrm{H}$ oxidation.

An advantage of the salen-iron complexes is their high robustness, which allows, for instance, TONs as high as 500 to be reached in sulfide oxidation. This feature prompted several studies aimed at immobilizing these catalysts on solid supports ${ }^{[33,115]}$ such as zeolites, ${ }^{[115,116]}$ zirconia, alumina ${ }^{[117,118]}$ or polymers ${ }^{[119]}$ facilitating reaction mixture separations and enabling the reuse of the catalyst. This strategy also enabled an increase of the conversions in $\mathrm{C}-\mathrm{H}^{[6,111,116,117]}$, and $\mathrm{C}=$ C oxidation reactions. ${ }^{[120,121]}$ However, some hints of a radical oxidation mechanism have been reported, such as preferential allylic oxidation in cyclohexene or $\mathrm{A} / \mathrm{K}$ ratios close to 1 . A cooperativity effect with salen-Fe and salen-Cu catalysts was observed. ${ }^{[122]}$ The results obtained with solid-supported catalysts have been recently reviewed. ${ }^{[93,119]}$

In 2009 a different tetradentate $\mathrm{N}_{2} \mathrm{~S}_{2}$ type iron(III) complex $\left[(\mathrm{gma} \cdot) \mathrm{Fe}\left(\mathrm{Bu}_{3} \mathrm{P}\right)\right]$ (see Figure 3 ) was reported to catalyze $\mathrm{C}-\mathrm{H}$ oxidation with $\mathrm{H}_{2} \mathrm{O}_{2}$ in the presence of pyrazinecarboxylic acid. ${ }^{[123]}$ The use of such an acid as an effective promoter in iron- and manganese-mediated oxidations was already known in the literature, ${ }^{[124]}$ and was found to be essential in this case too. The best results in cyclohexane oxidation were obtained at 0.01 and $0.1 \mathrm{~mol} \%$ of catalyst loading, with $10 \%$ yield $/ 490$ TON and $15 \%$ yield/75 TON, respectively (entry 5 of Table 1$)$. [(gma $\left.) \mathrm{Fe}\left(\mathrm{Bu}_{3} \mathrm{P}\right)\right]$ mediated also benzene hydroxylation to phenol, with a maximum $20 \%$ yield/110 TON. Inhibition of the oxidation by radical traps and cyclohexyl hydroperoxide detection definitely suggested a radical chain oxidation mechanism.

\subsection{Other Imine-Based Iron Complexes}

Schiff base ligands different from salen have been also investigated in the preparation of iron oxidation catalysts, and the results obtained in this field are reviewed in the present section.

Britovsek carried out a series of systematic structural modifications of non-heme iron complexes in order to evaluate their impact on the catalytic activity. ${ }^{[125-128]}$ During this investigation also imine-based complexes were considered. The tridentate iminopyridine complexes $\left[\left({ }^{\mathrm{R}} \mathrm{BIP}\right) \mathrm{Fe}(\mathrm{OTf})_{2}\right]$ (see Figure 4) were prepared, characterized and tested as oxidation catalysts in combination with $\mathrm{H}_{2} \mathrm{O}_{2}$ as the terminal oxidant. ${ }^{[129]}$

These catalysts displayed a sluggish catalytic activity in cyclohexane oxidation, with low $\mathrm{H}_{2} \mathrm{O}_{2}$ consumption and low $\mathrm{A} / \mathrm{K}$ ratios, with values close to those of $\mathrm{Fe}(\mathrm{OTf})_{2}$ (compare entries 3 and 4 and 2 of Table 2). Moreover, cyclohexyl hydroperoxide was detected in the product mixture (albeit only at a 10:1 substrate:oxidant ratio), and comparable results were report- 


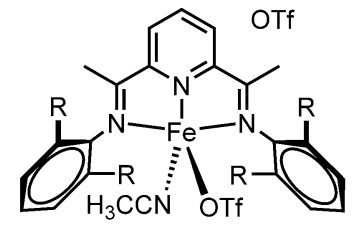

$\left[\left({ }^{\mathrm{R}} \mathrm{BIP}\right) \mathrm{Fe}\left(\mathrm{CH}_{3} \mathrm{CN}\right)(\mathrm{OTf})\right] \mathrm{OTf}$

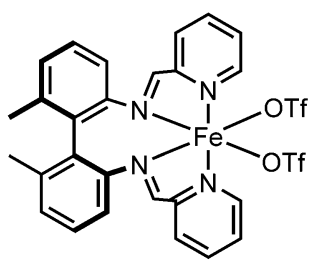

[(L2) $\left.\mathrm{Fe}(\mathrm{OTf})_{2}\right]$

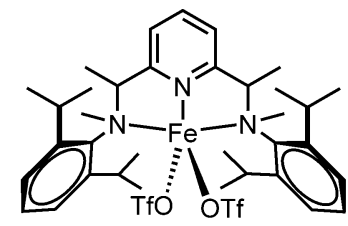

$\left[(\mathrm{L} 1) \mathrm{Fe}(\mathrm{OTf})_{2}\right]$

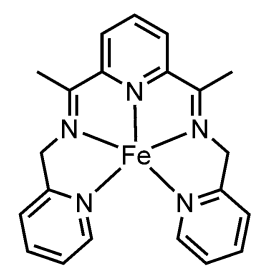

$\left[(\mathrm{L} 3) \mathrm{Fe}(\mathrm{OTf})_{2}\right]$
Figure 4.

ed irrespective of the counter ions used ( $\mathrm{Cl}$, OTf). Taken together, these results suggested a free radicalbased oxidation pathway. Since the saturated aminic analogous (complex $\left[(\mathbf{L 1}) \mathrm{Fe}(\mathrm{OTf})_{2}\right]$ in Figure 4) gave also Fenton-type activity (entry 5 of Table 2 ), the radical chain oxidation pathway was ascribed to the shared tridentate structure of such complexes, which probably disfavors a metal-based mechanism. ${ }^{[131]}$ However, similar results were achieved also with a tetradentate iminopyridine iron complex $\left[(\mathbf{L 2}) \mathrm{Fe}(\mathrm{OTf})_{2}\right]$ (Figure 4$),{ }^{[127]}$ although it was found to adopt the octahedral coordination mode with a cis- $\alpha$ topology which typically favors a metal-based oxidation. ${ }^{[132]}$ In the latter case the $\mathrm{H}_{2} \mathrm{O}_{2}$ consumption is slightly more efficient $(10 \%)$ (entry 6 of Table 2 ), but low A/K values and the cyclohexyl hydroperoxide presence (again only at higher oxidant:substrate ratios) in the products are indicative of a radical chain oxidation. The efficiency of oxidant consumption drops dramatically (2.6\%) upon increasing the $\mathrm{H}_{2} \mathrm{O}_{2}$ concentration, making this catalyst not suitable for efficient $\mathrm{C}-\mathrm{H}$ oxidations.

In 2010 Reedijk and Hage investigated the pentacoordinate iminopyridine iron complex $[(\mathbf{L 3}) \mathrm{Fe}(\mathrm{OT}$ f)](OTf) reported in Figure 4. ${ }^{[130]}$ The complex was found to be very oxygen-sensitive: it is rapidly oxidized to the $\mu$-oxo $\mathrm{Fe}(\mathrm{III})$ dimer $\left[(\mathbf{L 3})_{2} \mathrm{Fe}_{2}(\mathrm{O})(\mathrm{OTf})_{2}\right](\mathrm{OTf})_{2}$. Both the monomeric $[(\mathbf{L 3}) \mathrm{Fe}(\mathrm{OTf})](\mathrm{OTf})$ and the $\mu$-oxo dimer were tested as $\mathrm{C}-\mathrm{H}$ oxidation catalysts. The mononuclear iron(II) complex gave an $\mathrm{A} / \mathrm{K}$ value of 4.5 and a $3^{\circ} / 2^{\circ}$ ratio of 4.6 (entry 7 of Table 2) in cyclohexane and adamantane oxidation, respectively, while the dimer gave rise to a more selective oxidant (entry 8 of Table 2 ). The $\mathrm{A} / \mathrm{K}$ ratio was reported to decrease over time, suggesting initial oxidation of cyclohexane to cyclohexanol followed by subsequent overoxidation to ketone. The $\mu$-oxo dimer displayed a lower catalytic activity (2.9-4.6 TONs to be compared with 4.8-5.7). Increase of the oxidant/substrate ratio from $1: 100$ to $1: 10$ or higher values led to catalase-like activity (unproductive $\mathrm{H}_{2} \mathrm{O}_{2}$ consumption) for both catalysts.

A high interest lies in the search for catalysts able to efficiently convert cyclohexane into cyclohexanol and cyclohexanone, which is the bottleneck of the industrial adipic acid synthetic process. In this context, Reedijk and co-workers reported in $2007^{[133]}$ that the simple iminopyridine iron coordination complex dapab $\cdot \mathrm{Fe}\left(\mathrm{BF}_{4}\right)_{2}$ (Figure 5) is highly active in cyclohexane oxidation. $1 \mathrm{~mol} \%$ of such a complex allows the full oxidation of cyclohexane into a 1:1 ratio of cyclohexanol, cyclohexanone and traces of other by-products by reaction with $\mathrm{H}_{2} \mathrm{O}_{2}$ for $12 \mathrm{~h}$ at $50^{\circ} \mathrm{C}$ (entry 1 of Table 3 ). The reaction resulted to be faster under an argon atmosphere, with full conversion reached within 7 h. Cyclohexene oxidation gave mainly the allylic alcohol along with the corresponding unsaturated

Table 2. Oxidation of mechanistic probes mediated by iminopyridine iron complexes. ${ }^{[a]}$

\begin{tabular}{|c|c|c|c|c|c|c|}
\hline \multirow[t]{2}{*}{ Entry } & \multirow[t]{2}{*}{ Catalyst } & \multicolumn{3}{|c|}{ Cyclohexane $^{[\mathrm{b}]}$} & \multirow{2}{*}{$\begin{array}{l}\mathrm{AdH}^{[\mathrm{c}]} \\
3^{\circ} / 2^{\circ}\end{array}$} & \multirow[t]{2}{*}{ Ref. } \\
\hline & & $\mathrm{A} / \mathrm{K}$ & $\mathrm{H}_{2} \mathrm{O}_{2}$ Conv. [\%] & $\mathrm{CyOOH}$ & & \\
\hline 1 & {$\left[(\mathrm{TPA}) \mathrm{Fe}(\mathrm{OTf})_{2}\right]$} & 12 & 32 & $\mathrm{nd}^{[\mathrm{d}]}$ & 17 & {$[125]$} \\
\hline 2 & $\mathrm{Fe}(\mathrm{OTf})_{2}$ & 1.6 & 4 & $\mathrm{~d}^{[\mathrm{d}]}$ & 7 & {$[125]$} \\
\hline 3 & {$\left[\left({ }^{\mathrm{Me}} \mathrm{BIP}\right) \mathrm{Fe}(\mathrm{OTf})\left(\mathrm{CH}_{3} \mathrm{CN}\right)\right] \mathrm{OTf}$} & 1.0 & 5.2 & $\mathrm{nd}^{[\mathrm{e}]}$ & & [129] \\
\hline 4 & $\left.\left[{ }^{\text {iPr }} \mathrm{BIP}\right) \mathrm{Fe}(\mathrm{OTf})\left(\mathrm{CH}_{3} \mathrm{CN}\right)\right] \mathrm{OTf}$ & 1.5 & 4.9 & $\mathrm{nd}^{[\mathrm{e}]}$ & & [129] \\
\hline 5 & {$\left[(\mathbf{L 1}) \mathrm{Fe}(\mathrm{OTf})_{2}\right]$} & 1.3 & 3.9 & $\mathrm{nd}^{[\mathrm{e}]}$ & & [128] \\
\hline 6 & {$\left[(\mathbf{L 2}) \mathrm{Fe}(\mathrm{OTf})_{2}\right]$} & 1.3 & 10 & $\mathrm{nd}^{[\mathrm{e}]}$ & & [127] \\
\hline 7 & {$[(\mathbf{L 3}) \mathrm{Fe}(\mathrm{OTf})] \mathrm{OTf}$} & 4.5 & 44 & - & 4.6 & [130] \\
\hline 8 & {$\left[(\mathbf{L 3})_{2} \mathrm{Fe}(\mu-\mathrm{O})\right](\mathrm{OTf})_{4}$} & 7.2 & 41 & - & 9.4 & {$[130]$} \\
\hline
\end{tabular}

[a] Reaction conditions: catalyst: $\mathrm{H}_{2} \mathrm{O}_{2}$ :substrate 1:10:100, $\mathrm{CH}_{3} \mathrm{CN}$, air, room temperature.

[b] 1000 molar equivalents of cyclohexane.

[c] $\mathrm{AdH}=$ adamantane. 10 molar equivalents of substrate.

[d] $\mathrm{nd}=$ not detected; $\mathrm{d}=$ detected.

[e] Not detected with 10 mol. equiv. of $\mathrm{H}_{2} \mathrm{O}_{2}$, but detected with 100 mol. equiv 
<smiles>COc1ccccc1CN=C(C)c1cccc(C(C)=NCc2ccccc2OC)n1</smiles>

dapab

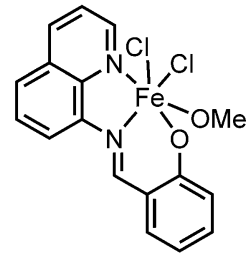

$\left[(\mathrm{mqmp}) \mathrm{Fe}\left(\mathrm{CH}_{3} \mathrm{OH}\right)(\mathrm{Cl})_{2}\right]$<smiles>CC(=NCc1ccccc1)c1cccc(C(C)=NCc2ccccc2)n1</smiles>

dapb

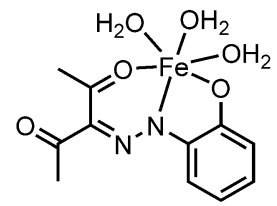

$\left[(\mathrm{ABHD}) \mathrm{Fe}\left(\mathrm{H}_{2} \mathrm{O}\right)_{3}\right]$<smiles>Oc1ccccc1/C=N/CCN1CCNCC1</smiles>

L4

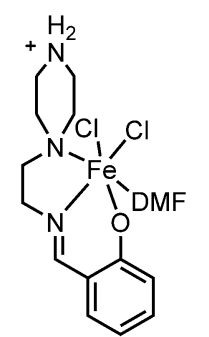

$\left[(\mathrm{L} 4) \mathrm{Fe}(\mathrm{DMF})(\mathrm{Cl})_{2}\right]$

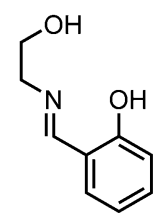

$\mathrm{H}_{2} \mathrm{Sae}$
Figure 5.

ketone, while cyclooctene was selectively epoxidized. Reaction was inhibited by scavengers of $\mathrm{HO}^{\circ}$ radicals like DMSO and acetone. This evidence, taken together with the presence of unidentified by-products in cyclohexane oxidation, pointed to an efficient oxidation mediated by hydroxyl radicals.
One year later, ${ }^{[134]}$ the same authors reported a slightly modified version of the previous dapab ligand, devoid of the two methoxy groups (ligand dapb in Figure 5) but with lower oxidation performances. The new ligand led to a decrease in reaction rate (full conversion reached only in $22 \mathrm{~h}$ ) and a lower selectivity (see Table 3 ). These observations were ascribed to the lower stability of the dapb ligand, which was reported to hydrolyze under the reaction conditions.

Unexpectedly, full conversion of cyclohexane to the oxidation products was achieved also in the presence of only the $\mathrm{Fe}(\mathrm{II})$ salt without any ligand $\left(50^{\circ} \mathrm{C}\right.$ and $22 \mathrm{~h}$ ). A series of $\mathrm{Fe}(\mathrm{II})$ salts with different counterions was then investigated (Table 3 ). $\mathrm{Fe}\left(\mathrm{ClO}_{4}\right)_{2}$ gave the highest selectivity. The iron oxidation state did not affect the reaction (compare entries 5 and 6 of Table 3), while different counter ions $\left(\mathrm{Cl}, \mathrm{BF}_{4}\right)$ increased the amounts of cyclohexyl hydroperoxide and other unidentified by-products (see Table 3). The presence of ligand dapb enhanced the selectivity for cyclohexanol and cyclohexanone formation. The authors suggested that two competing reaction pathways are operating, a metal-based one and a free-radical one mediated by hydroxyl radicals. However, the dominance of the radical chain, unselective oxidation pathway poses a severe limit on the use of such catalytic systems in synthetically useful $\mathrm{C}-\mathrm{H}$ oxidations.

In 2010 the $\mathrm{Fe}(\mathrm{III})$ complex of a tridentate Schiff base ligand $\left[(\mathrm{mqmp}) \mathrm{Fe}\left(\mathrm{CH}_{3} \mathrm{OH}\right)(\mathrm{Cl})_{2}\right]$ (see Figure 5) was reported to exhibit a good catalytic activity in hydrocarbon oxidation. ${ }^{[135]}$ This complex was structurally and spectroscopically characterized. Total conversion in cyclohexane oxidation by $\mathrm{H}_{2} \mathrm{O}_{2}$ was reached in $24 \mathrm{~h}$ at $50^{\circ} \mathrm{C}$ (entry 7 of Table 3 ), and the reaction performed comparably under argon. Cyclohexyl hydroperoxide was detected in the initial stages of the reac-

Table 3. Cyclohexane oxidation mediated by iminopyridine iron complexes and iron salts. ${ }^{[a]}$

\begin{tabular}{|c|c|c|c|c|c|c|c|c|c|}
\hline \multirow[t]{2}{*}{ Entry } & \multirow[t]{2}{*}{ Catalyst } & \multicolumn{4}{|c|}{ Cyclohexane Oxidation Yields [\%] } & \multirow[t]{2}{*}{ Reaction Time } & \multirow[t]{2}{*}{ Cat. Loading } & \multirow[t]{2}{*}{ TON } & \multirow[t]{2}{*}{ Ref } \\
\hline & & $\mathrm{CyOH}$ & $\mathrm{CyO}$ & $\mathrm{CyOOH}$ & By-products & & & & \\
\hline 1 & {$\left[(\mathrm{dapab}) \mathrm{Fe}\left(\mathrm{BF}_{4}\right)_{2}\right]$} & 49 & 49 & 0 & $<1$ & $12 \mathrm{~h}$ & $1 \%$ & 98 & {$[133]$} \\
\hline 2 & {$\left[(\mathrm{dapb}) \mathrm{Fe}\left(\mathrm{BF}_{4}\right)_{2}\right]$} & 32 & 42 & 6 & 19 & $22 \mathrm{~h}$ & $1 \%$ & 80 & [134] \\
\hline 3 & $\mathrm{Fe}\left(\mathrm{BF}_{4}\right)_{2}$ & 29 & 19 & 34 & 19 & $22 \mathrm{~h}$ & $1 \%$ & 82 & [134] \\
\hline 4 & {$\left[(\mathrm{dapb}) \mathrm{Fe}\left(\mathrm{ClO}_{4}\right)_{2}\right]$} & 37 & 54 & ${ }^{[\mathrm{b}]}$ & 9 & $22 \mathrm{~h}$ & $1 \%$ & 91 & [134] \\
\hline 5 & $\mathrm{Fe}\left(\mathrm{ClO}_{4}\right)_{2}$ & 27 & 60 & - & 13 & $22 \mathrm{~h}$ & $1 \%$ & 87 & [134] \\
\hline 6 & $\mathrm{Fe}\left(\mathrm{ClO}_{4}\right)_{3}$ & 25 & 55 & - & 20 & $22 \mathrm{~h}$ & $1 \%$ & 80 & {$[134]$} \\
\hline 7 & {$\left[(\mathrm{mqmp}) \mathrm{Fe}\left(\mathrm{CH}_{3} \mathrm{OH}\right)(\mathrm{Cl})_{2}\right]^{[\mathrm{b}]}$} & 39 & 51 & $Z^{[\mathrm{e}]}$ & $<10$ & $24 \mathrm{~h}$ & $1 \%$ & 90 & {$[135]$} \\
\hline 8 & {$\left[(\mathrm{ABHD}) \mathrm{Fe}\left(\mathrm{H}_{2} \mathrm{O}\right)_{3}\right]^{[\mathrm{b}, \mathrm{d}]}$} & 11 & 15 & $-^{[\mathrm{e}]}$ & $<1$ & $6 \mathrm{~h}$ & $1 \%$ & 50 & [136] \\
\hline 9 & {$\left[(\mathrm{Sae})_{8} \mathrm{Co}_{4} \mathrm{Fe}_{2}(\mathrm{O})\right]^{[\mathrm{b}]}$} & 29 & 2 & $-^{[\mathrm{e}]}$ & $<1$ & $6 \mathrm{~h}$ & 0.02 & 1600 & {$[137]$} \\
\hline 10 & {$\left[(\mathbf{L 4}) \mathrm{Fe}(\mathrm{DMF})(\mathrm{Cl})_{2}\right]^{[\mathrm{b}]}$} & $37(\mathrm{~A}+$ & & $-^{[\mathrm{e}]}$ & $<5$ & $5 \mathrm{~h}$ & 0.002 & 900 & {$[138]$} \\
\hline
\end{tabular}

[a] Reaction conditions: catalyst: $\mathrm{H}_{2} \mathrm{O}_{2}$ :substrate 1:150:100, $\mathrm{CH}_{3} \mathrm{CN}$, air, $50{ }^{\circ} \mathrm{C}, 22 \mathrm{~h}$.

[b] $\mathrm{HNO}_{3}$ was added as a promoter (50 molar equivalents with respect to catalyst).

[c] Pyrazinecarboxylic acid was added as a promoter (50 molar equivalents with respect to cyclohexane).

[d] Reaction was carried out at $25^{\circ} \mathrm{C}$.

[e] $\mathrm{CyOOH}$ was detected, but $\mathrm{Ph}_{3} \mathrm{P}$ addition prior to $\mathrm{GC}$ analysis quantitatively reduced it to $\mathrm{CyOH}$. 
tion, and then gradually disappeared. Hydroxyl radical scavengers such as DMSO significantly inhibited the reaction. Cyclohexene oxidation again gave allylic alcohol and the corresponding ketone, typical products of a free radical oxidation. All these clues pointed to a free radical oxidation. However, the authors reported also the detection of an $\left[(\mathrm{mqmp}) \mathrm{Fe}\left(\mathrm{CH}_{3} \mathrm{OH}\right)(\mathrm{Cl})(\mathrm{O})\right]$ species during the ESIMS monitoring of the reaction and proposed such a high-valent iron species to be the oxidizing intermediate. No further study to confirm this assignment has been carried out. Likely a radical chain autoxidation pathway was competing with a metal-based oxidant.

In 2012 Pombeiro et al. ${ }^{[136]}$ described a similar tridentate hydrazone-based ligand ABHD and the corresponding $\mathrm{Fe}(\mathrm{III})$ complex $\left[(\mathrm{ABHD}) \mathrm{Fe}\left(\mathrm{H}_{2} \mathrm{O}\right)_{3}\right]$ (see Figure 5). This complex is competent for the room temperature oxidation of a series of cycloalkanes in combination with $\mathrm{H}_{2} \mathrm{O}_{2}$ and $\mathrm{HNO}_{3}$. Yields up to $25 \%$ were reported, depending on catalyst and $\mathrm{HNO}_{3}$ concentration. Radical traps (such as TEMPO or $\mathrm{CBrCl}_{3}$ ) inhibited the reaction, suggesting a mechanism involving freely diffusing carbon- and oxygen-centered radicals.

Very recently a new Schiff base iron complex was reported to be highly active in $\mathrm{C}-\mathrm{H}$ oxidation (ligand L4 in Figure 5). ${ }^{[138]}$ The complex was assembled insitu, and was found to adopt a slightly distorted octahedral structure, with the distal nitrogen of the piperazine ring protonated. Very low catalyst loadings (0.05-0.2 mol\%) are required to display an impressive catalytic activity in cyclohexane oxidation by $\mathrm{H}_{2} \mathrm{O}_{2}$, with $37 \%$ yield and 900 TON (entry 10 of Table 3 ). $\mathrm{HNO}_{3}$ (in a minimum acid:catalyst ratio of 50:1) is necessary to achieve these results. According to the authors, the role of nitric acid is to induce a catalyst reorganization in combination with $\mathrm{H}_{2} \mathrm{O}_{2}$. By-products generated by a radical chain oxidation were detected in a total yield of $1-5 \%$ depending on catalyst concentration. Moreover, a low selectivity for tertiary over secondary $\mathrm{C}-\mathrm{H}$ bonds and no stereospecificity in 1,2-cis-dimethylcyclohexane oxidation were reported. These observations definitely pointed to oxidation promoted by hydroxyl radicals.

Similar high activity in hydrocarbon oxidation due to efficient formation of hydroxyl radicals was observed by Pombeiro and Kokozay with a heterometallic $\left[\mathrm{Co}(\mathrm{III})_{4} \mathrm{Fe}(\mathrm{III})_{2}(\mathrm{Sae})_{8}\right]$ imine-based complex, obtained by self-assembly of $\mathrm{Co}, \mathrm{Fe}(\mathrm{II})$ and the tridentate $\mathrm{H}_{2}$ Sae ligand (see Figure 5) in DMF solution. ${ }^{[137]}$ Its solid state structure showed a hexanuclear array composed of two trinuclear $\left[\mathrm{Co}_{2} \mathrm{Fe}(\mathrm{Sae})_{4}\right]$ fragments linked by a single oxygen atom, while metal oxidation states were determined by EPR and Mössbauer analyses. This structure degrades under the reaction conditions with the formation of the active heterometallic
$\left[\mathrm{Co}_{2} \mathrm{Fe}(\mathrm{Sae})_{4}\right]$ species detected by ESI-MS. A surprisingly high activity in $\mathrm{C}-\mathrm{H}$ bond oxidation using $\mathrm{H}_{2} \mathrm{O}_{2}$ as terminal oxidant and $\mathrm{HNO}_{3}$ as a promoter was reported, with cyclohexane oxygenated in $31 \%$ yield/ 1600 TON and $26 \%$ yield/3670 TON depending on catalyst loading. $\mathrm{HNO}_{3}$ was again essential, since no activity was observed in its absence. Mechanistic investigations pointed to a Fenton-type oxidation process, with highly efficient hydroxyl radical generation. Interestingly, replacement of $\mathrm{H}_{2} \mathrm{O}_{2}$ with $m$ CPBA led to stereospecific oxidations. The latter evidence suggested a shift from a free-radical to a metal-based mechanism.

In 2011 Bauer studied a series of iminopyridine iron complexes, ${ }^{[139]}$ formed by reaction of $\mathrm{Fe}(\mathrm{II})$ triflate with two molar equivalents of bidentate iminopyridine ligands (see Figure 6). The imine ligands prefer a cis coordination mode, but ortho substituents on the aniline ring enforce a trans coordination. However dynamic interconversion of the isomers was observed in $\mathrm{CH}_{3} \mathrm{CN}$ solution. With high $\mathrm{H}_{2} \mathrm{O}_{2}$ /cyclohexane ratios (100:1 or 10:1) no products were detected, while a decrease of this ratio to $0.5: 1$ or $1: 1$ allowed the formation of cyclohexanol and cyclohexanone, albeit with low conversion $\left(\mathrm{H}_{2} \mathrm{O}_{2}\right.$ consumption 3$16 \%)$. Low $\mathrm{A} / \mathrm{K}$ ratios (0.37-0.61) were reported, and the reaction did not proceed in the presence of a radical scavenger (2,4,6-tri-tert-butylphenol), indicating a radical-chain oxidation mechanism. A tendency towards catalyst degradation under the adopted reaction conditions was definitely observed. In a following study ${ }^{[140]}$ the same authors found that the main degradation product is the corresponding amide complex. Similar A/K values (0.19) were reported with $t$ $\mathrm{BuOOH}$ as the oxidant. Interestingly, benzylic $\mathrm{C}-\mathrm{H}$

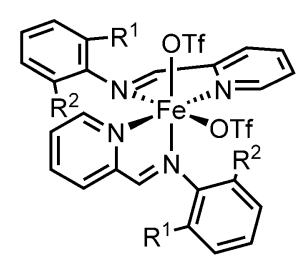

cis

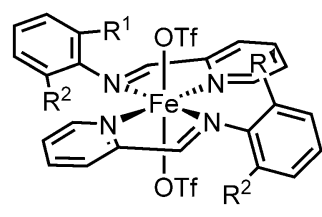

trans

$\mathrm{R}^{1}=\mathrm{R}^{2}=\mathrm{H}:\left[(\mathrm{L} 5)_{2} \mathrm{Fe}(\mathrm{OTf})_{2}\right]$ $\mathrm{R}^{1}=\mathrm{R}^{2}=\mathrm{Me}, \mathrm{Et}, \ldots$

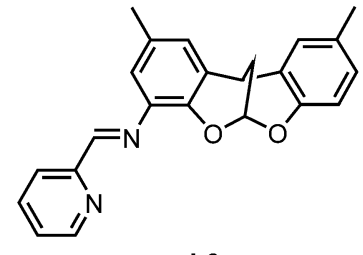

L6

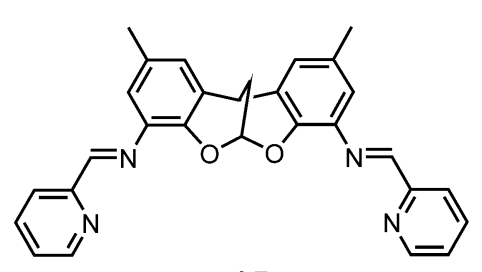

L7
Figure 6. 
Table 4. Diphenylmethane oxidation mediated by iminopyridine iron complexes and iron salts with $t$-BuOOH at room temperature. $^{[\mathrm{a}]}$

\begin{tabular}{|c|c|c|c|}
\hline Entry & Catalyst & Yield (\%) & Ref. \\
\hline 1 & {$\left[(\mathbf{L 5})_{2} \mathrm{Fe}(\mathrm{OTf})_{2}\right]^{[\mathrm{a}]}$} & 74 & {$[137]$} \\
\hline 2 & {$\left[(\mathbf{L 6})_{2} \mathrm{Fe}\left(\mathrm{CH}_{3} \mathrm{CN}\right)_{2}\right]\left(\mathrm{BF}_{4}\right)_{2}{ }_{2}^{[\mathrm{b}]}$} & 41 & {$[138]$} \\
\hline 3 & {$\left[(\mathbf{L 7})_{2} \mathrm{Fe}_{2}\left(\mathrm{CH}_{3} \mathrm{CN}\right)_{4}\right]\left(\mathrm{BF}_{4}\right)_{4}^{[\mathrm{b}]}$} & 73 & {$[138]$} \\
\hline
\end{tabular}

bonds were oxidized to ketones in moderate-to-excellent yields (22-91\%, entry 1 of Table 4$)$ with $t$ $\mathrm{BuOOH}$. Under the latter conditions, the reaction was not inhibited by radical scavengers. Substitution on the aniline ring exerted only a minor influence on reaction rate and almost no differences in yields. Overall, the collected data did not allow extraction of a clear mechanistic picture of the oxidation process with $t$ - $\mathrm{BuOOH}$, while oxidation with $\mathrm{H}_{2} \mathrm{O}_{2}$ is more in line with a Fenton-type process.

In $2015^{[141]}$ Van Leuween, Claver and Britovsek investigated a binuclear version (see Figure 6) of the simple iminopyridine complex described by Bauer ${ }^{[139]}$ as a catalyst in benzylic $\mathrm{C}-\mathrm{H}$ oxidation reactions. This complex adopted a cis coordination geometry analogous to $\left[(\mathbf{L 5})_{2} \mathrm{Fe}(\mathrm{OTf})_{2}\right]$. Moderate to good yields were reported (see Table 4), and the highest yields were again obtained with $t$-BuOOH as the oxidant, while $\mathrm{H}_{2} \mathrm{O}_{2}$ and $m$ CPBA performed poorly. Since the mononuclear complex $\left[(\mathbf{L 6})_{2} \mathrm{Fe}\left(\mathrm{CH}_{3} \mathrm{CN}\right)_{2}\right]\left(\mathrm{BF}_{4}\right)_{2}$ was found to have a comparable activity, cooperativity between the two iron sites of $\left[(\mathbf{L 7})_{2} \mathrm{Fe}_{2}\left(\mathrm{CH}_{3} \mathrm{CN}\right)_{4}\right]\left(\mathrm{BF}_{4}\right)_{4}$ was excluded. Oxidation of a series of substituted ethylbenzenes proved the electrophilic nature of the oxidant, with electron-rich substrates giving higher conversions than the electron-poor ones. No further mechanistic investigations of the oxidations promoted by this complexes have been carried out.

In 2013 Kovacs and co-workers ${ }^{[142]}$ reported a five coordinated $\mathrm{Fe}(\mathrm{II})$ complex, in which the pentadentate iminopyridine ligand displayed an alkoxide arm. $\mathrm{O}_{2}$ addition to this coordinatively unsaturated complex affords a dihydroxo bridged $\mathrm{Fe}(\mathrm{III})$ dimer (Scheme 12), with an $\mathrm{Fe}_{2} \mathrm{O}_{2}$ core structure resembling the one found in the MMO active site. The O-atoms of the hydroxo bridges derive from $\mathrm{O}_{2}$, while the $\mathrm{H}$ atoms come from the solvent (acetonitrile), as demonstrated by isotopic labeling studies. Hydrogen atom abstraction from inert $\mathrm{CH}_{3} \mathrm{CN}$ suggested the involvement of a highly oxidizing metastable intermediate, which eventually formed the bis $\mu-\mathrm{OH}$ dimer. The same dimer was obtained upon treatment of the initial complex with a different oxidant (namely $\mathrm{PhIO}$ ). The final hydroxo bridged complex was able to oxidize the activated $\mathrm{C}-\mathrm{H}$ bonds of dihydroanthracene.

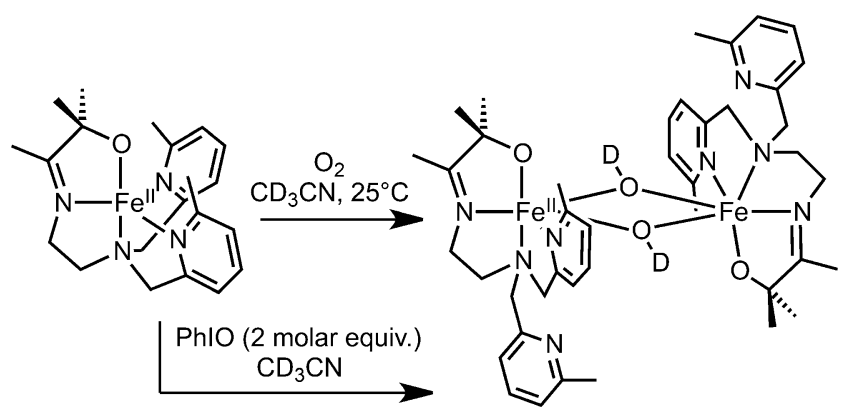

Scheme 12. Reaction of the pentadentate iron complex with $\mathrm{O}_{2}$ to afford the $\mu$-oxo dimer able to abstract $\mathrm{D}$-atom from $\mathrm{CD}_{3} \mathrm{CN}$.

We recently reported that the simple imine-based non-heme $\mathrm{Fe}(\mathrm{II})$ complex $\left\{\left[(\mathbf{L 8})_{2} \mathrm{Fe}\right](\mathrm{OTf})_{2}\right.$ depicted in Scheme 13\} catalyzes aliphatic $\mathrm{C}-\mathrm{H}$ hydroxylation with high efficiency. ${ }^{[143]}$ Its catalytic activity (yields up to $47 \%$ and TON in the range $25-50$ ) is comparable to that of several more elaborate amine-based complexes, and higher than that of most imine-based ones. The main advantage offered by $\left[(\mathbf{L 8})_{2} \mathrm{Fe}\right](\mathrm{OTf})_{2}$ is its great ease of preparation, since no previous synthetic steps are required. Conveniently, the precursors of this complex [2-picolyl aldehyde, 2-picolylamine and $\mathrm{Fe}(\mathrm{OTf})_{2}$ in a 2:2:1 molar ratio] can be rapidly and quantitatively assembled in situ just before substrate and oxidant $\left(\mathrm{H}_{2} \mathrm{O}_{2}\right)$ addition (see Scheme 13). ${ }^{[144]}$

A thorough mechanistic investigation has been carried out on this iminopyridine iron catalyst. ${ }^{[145]}$ At first, some of the experiments described in the first section of this review have been carried out to establish if the oxidations catalyzed by $\left.\left[(\mathbf{L 8})_{2} \mathrm{Fe}\right](\mathrm{OTf})_{2}\right]$ are metal-based or follow radical chain reactions. Results of mechanistic probe oxidations are summarized in Table 5, and they strongly indicate the involvement of a selective, metal-based oxidant, as demonstrated by the high retention of configuration in 1,2-cis-dimethylcyclohexane oxidation. Remarkably, isotope labeling experiments showed that the $\mathrm{O}$-atom incorporated in the products largely comes from $\mathrm{H}_{2} \mathrm{O}_{2}$, suggesting

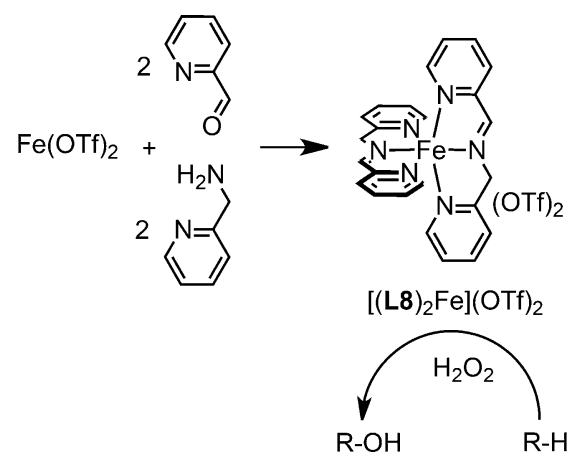

Scheme 13. 
Table 5. Mechanistic probe oxidation mediated by catalyst $\left[(\mathbf{L 8})_{2} \mathrm{Fe}(\mathrm{OTf})_{2}\right]$ and $\mathrm{Fe}(\mathrm{OTf})_{2} / \mathrm{H}_{2} \mathrm{O}_{2}$. ${ }^{[a]}$

\begin{tabular}{|c|c|c|}
\hline $\begin{array}{l}\text { Mechanistic Probe } \\
\text { column } 1\end{array}$ & $\begin{array}{l}\text { Catalyst } \\
{\left[(\mathrm{L} 8)_{2} \mathrm{Fe}\right](\mathrm{OTf})_{2}{ }^{[145]}}\end{array}$ & $\mathrm{Fe}(\mathrm{OTf})_{2}{ }^{[125]}$ \\
\hline $\mathrm{A} / \mathrm{K}$ & 11.5 & 1.6 \\
\hline KIE & 3.3 & n.d. \\
\hline $3^{\circ} / 2^{\circ[b]}$ & 13 & \\
\hline $\mathrm{RC}$ & 97 & $27^{[\mathrm{c}]}$ \\
\hline $\mathrm{CyOOH}^{[\mathrm{d}]}$ & no & yes \\
\hline $\mathrm{H}_{2} \mathrm{O} \mathrm{O}$-incorporation & $<1 \%$ & n.d. \\
\hline $\mathrm{H}_{2} \mathrm{O}_{2}$ O-incorporation & $80-96 \%$ & n.d. \\
\hline \multicolumn{3}{|c|}{$\begin{array}{l}\text { [a] Reaction conditions: cat: } \mathrm{H}_{2} \mathrm{O}_{2}: \mathrm{AcOH}: \text { substrate }= \\
1: 10: 50: 100 \text {. } \\
\text { [b] } 3^{\circ} / 2^{\circ}=3 \times(1 \text {-adamantanol }) /(2 \text {-adamantanol + } 2 \text {-adaman- } \\
\text { tanone }) \text {. } \\
\text { [c] Determined with } \mathrm{Fe}\left(\mathrm{ClO}_{4}\right)_{2} \text {, see ref. }{ }^{[13]} \\
\text { [d] Detected with the Shul'pin test. }\end{array}$} \\
\hline
\end{tabular}

again a preponderant metal-based mechanism. ${ }^{[146]} \mathrm{Un}$ expectedly, no $\mathrm{O}$-atom incorporation from $\mathrm{H}_{2} \mathrm{O}$ was observed $(<1 \%)$. Moreover, acetic acid exerted only a negligible effect on catalytic activity. These observations suggested that the supposed high-valent intermediate has no possibility to coordinate both the hydroperoxide and a second ligand (water or acetic acid) which can favor $\mathrm{O}^{-} \mathrm{O}$ heterolysis, and to undergo oxo-hydroxo tautomerism. These considerations implied a mechanism different from the one operating in the majority of aminopyridine iron complexes with two cis labile sites. ${ }^{[39,42]}$

Scheme 14 shows the proposed mechanism of the initial steps of $\left[(\mathbf{L 8})_{2} \mathrm{Fe}\right](\mathrm{OTf})_{2}$ catalytic cycle, up to the formation of a hydroperoxo complex. The initial, rate-determining oxidation of the $\mathrm{Fe}(\mathrm{II})$ complex to
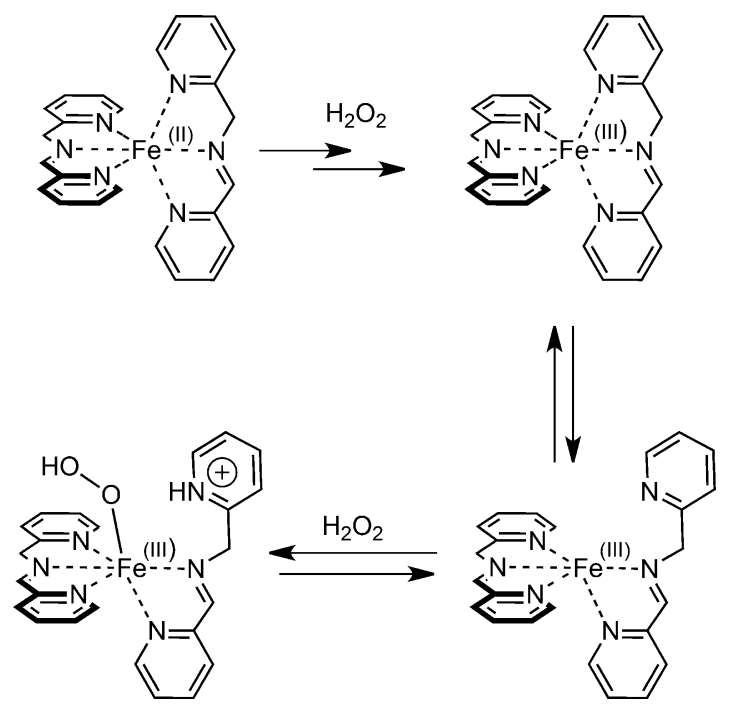

Scheme 14. Proposed mechanism for the formation of the hydroperoxo complex intermediate in the $\mathrm{C}-\mathrm{H}$ oxidation pathway mediated by $\left[(\mathbf{L 8})_{2} \mathrm{Fe}\right](\mathrm{OTf})_{2}$.
$\mathrm{Fe}(\mathrm{III})$ allows the catalytic cycle to start. Subsequent detachment of a pyridine arm would allow the coordination and activation of $\mathrm{H}_{2} \mathrm{O}_{2}$, generating the oxidizing species whose exact nature has still to be clarified. Catalyst evolution was followed by ESI-MS throughout the oxidation reaction, and no ligand dissociation or hydrolysis was observed. Catalyst deactivation due to oxidation of the picolinic ligand to the corresponding amide was observed during the reaction with a consequent reduction of the catalytic activity.

Also the recent and seminal work by Xiao and coworkers on the aminal-based ligand $\mathbf{L 9}$ depicted in Scheme 15 can be included in the present survey, since aminals are very close relatives of imines. Reaction of $\mathrm{Fe}(\mathrm{II})$ with $\mathbf{L 9}$ generates a 1:1 tridentate complex which is able to activate molecular oxygen for hydrocarbon oxidations. ${ }^{[14]}$ The above complex was found to catalyze the $\alpha$-oxidation of ethers to lactones or esters with $\mathrm{O}_{2}$ as the terminal oxidant (Scheme 15a). The catalyst loading was surprisingly low, and TONs up to 412 were obtained. Interestingly, the catalyst can be prepared in situ. $\mathrm{O}_{2}$ was the exclusive $\mathrm{O}$-source, and $\mathrm{H}_{2}$ is generated as the by-product. The involvement of free diffusing radicals was ruled out, since cyclopropyl-based radical clocks do not rearrange under the reaction conditions. Inhibition of the reaction by radical traps is probably caused by coordination of the latter to the iron complex and consequent catalyst poisoning (vide supra). The peroxide intermediate depicted between parentheses in

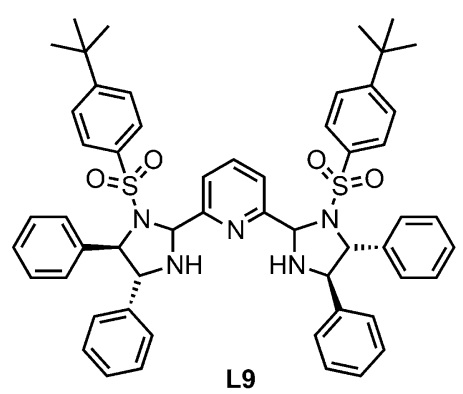

(a)
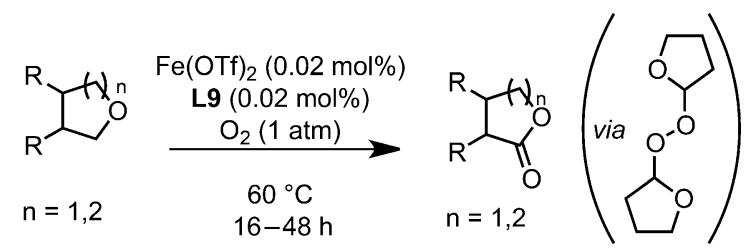

(b)

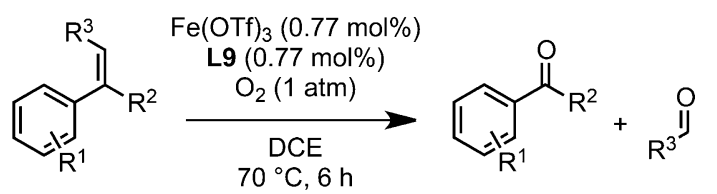

Scheme 15. Oxidative transformations catalyzed by an Feaminal complex $\left(\left[(\mathbf{L 9}) \mathrm{Fe}(\mathrm{OTf})_{2}(\mathrm{THF})\right]\right.$ or $\left.\left[(\mathbf{L 9}) \mathrm{Fe}(\mathrm{OTf})_{3}\right]\right)$ and $\mathrm{O}_{2}$. 
Scheme 15a was found to convert into two molecules of the ester product and $\mathrm{H}_{2}$ in the presence of catalyst $\left[(\mathbf{L 9}) \mathrm{Fe}(\mathrm{OTf})_{2}(\mathrm{THF})\right]$. On these bases a catalytic cycle has been proposed, in which the complex reacts with $\mathrm{O}_{2}$ to form an iron superoxide intermediate coordinating substrate molecules. Such an intermediate would evolve into the peroxide (Scheme 15a) and an iron dihydride species which in turn releases $\mathrm{H}_{2}$ and regenerates the catalyst (Scheme 16).

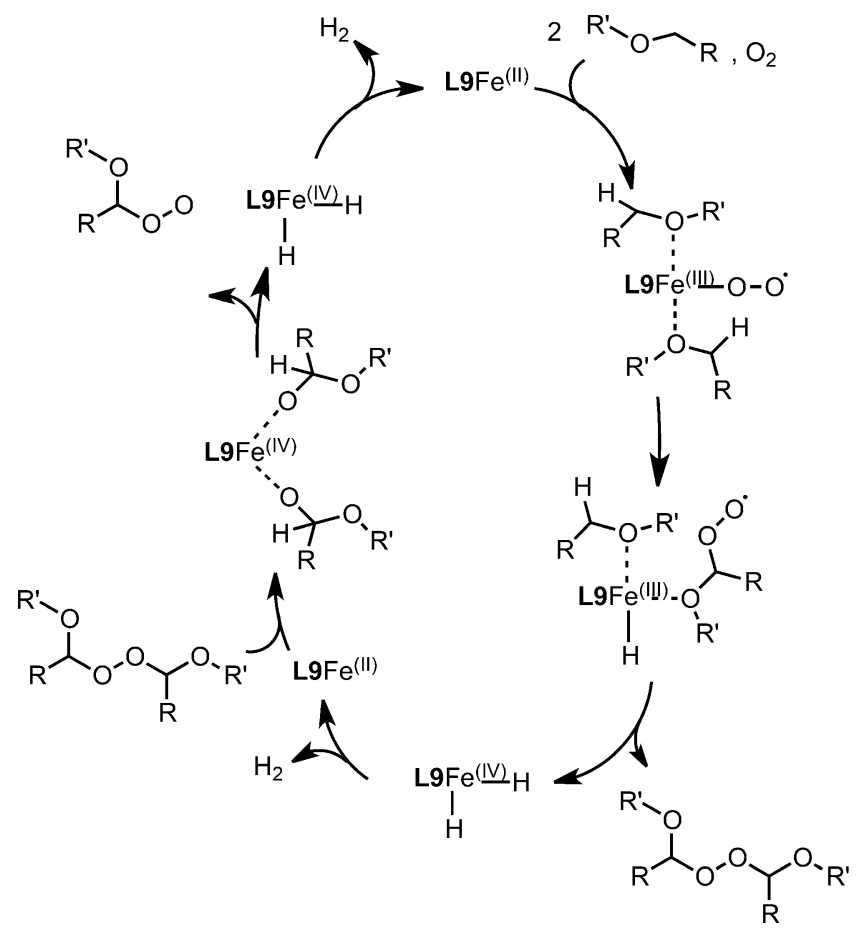

Scheme 16. Mechanism of ether oxidation by complex L9Fe(II). ${ }^{[147]}$

Very recently, the $\mathrm{Fe}(\mathrm{III})$ complex of the same ligand L9, [(L9)Fe(OTf $)_{3}$ ], was described as an efficient catalyst for the oxidative cleavage of $\mathrm{C}=\mathrm{C}$ bonds with $\mathrm{O}_{2} \cdot{ }^{[148]}$ This attractive transformation is clean and operationally simple, and was reported to furnish the aldehyde or ketone products in high yield (60-96\%) from substituted styrenes (Scheme 15b). Again, the reaction does not involve free diffusing radicals (vide supra), but is inhibited by radical traps, which poison the catalyst. Neither a reactive singlet $\mathrm{O}_{2}$ is generated in situ, nor do carbocation intermediates appear along reaction pathways. A catalytic cycle has been proposed, with initial coordination of the olefin to the iron center followed by formation of an Fe-superoxide intermediate. The peroxide would insert into the olefin forming a five-coordinated metallacycle, which collapses into a dioxetane and releases the catalyst. Dioxetanes are known to eventually rearrange in the reaction products (Scheme 15b). ${ }^{[148]}$
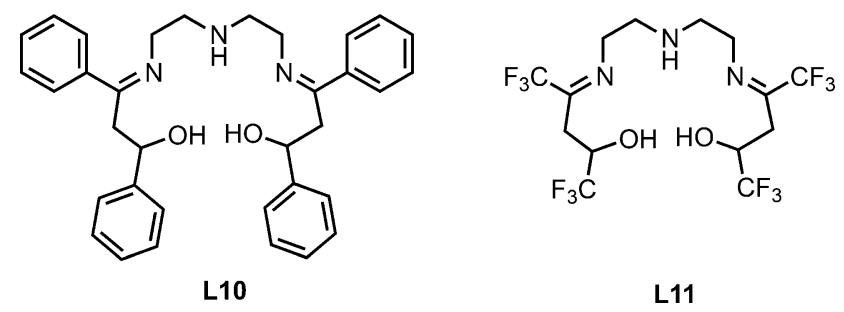

Scheme 17. Ligands employed by Louloudi and co-workers.

A pentadentate imine-based ligand $(\mathbf{L 1 0}$ in Scheme 17) was used by Louloudi and co-workers in the preparation of $\mathrm{Fe}$ (III) catalysts for oxidation reactions. ${ }^{[149,150]}$ Both $\mathrm{H}_{2} \mathrm{O}_{2}$ and $t$ - $\mathrm{BuOOH}$ were effective as terminal oxidants. The related $(\mathbf{L 1 1}) \mathrm{FeCl}$ complex was found to be more reactive (shorter reaction times) but more prone to oxidative degradation. Acetonitrile solvent gave the highest activity, while less polar solvents decreased conversion. (L10)FeCl and (L11) FeCl catalyzed the conversion of cyclohexene into a mixture of cyclohexenol, cyclohexenone (main products) and cyclohexene epoxide with high efficiency $(88 \%$ conversion). Styrene was converted to the corresponding epoxide and benzaldehyde, and cyclohexane was oxidized into a mixture of alcohol and ketone $(A / K=1.75)$. The reactions were carried out under an argon purge, since the presence of atmospheric $\mathrm{O}_{2}$ deeply influenced the oxidation outcomes. These results pointed to a radical-based oxidation mechanism. Such a mechanistic pathway was further confirmed by the detection of cyclohexene-OO-t-Bu adducts in trace amounts when $t$ - $\mathrm{BuOOH}$ is used as the oxidant ${ }^{[151]}$ and inhibition of the oxidation by radical traps for carbon- $\left(\mathrm{CBrCl}_{3}\right)$ and oxygen-centered radicals $\left(\mathrm{Ph}_{2} \mathrm{NH}, \mathrm{DMPO}\right) .{ }^{[150]}$ The latter radicals $(\mathrm{HO} \cdot$ and the oxyl radical of cyclohexenol) were trapped as DMPO adducts (vide supra) and identified by EPR, following the method described by Beller. ${ }^{[82]}$ Reaction of the complexes with $\mathrm{H}_{2} \mathrm{O}_{2}$ was studied by UV-Vis and EPR spectroscopy and the formation of (L10)FeOOH and (L11)FeOOH intermediates was proposed. Such low-spin intermediates have been found to slowly build up and then decay in the presence of the substrates. ${ }^{[150]}$ On these bases, the authors proposed that the $\mathrm{Fe}(\mathrm{III})$ hydroperoxide undergoes $\mathrm{O}-\mathrm{O}$ homolysis, generating $\mathrm{HO}^{*}$ and $\mathrm{LFe}(\mathrm{IV})=\mathrm{O}$, which in turn initiate the oxidation process. Immobilization of the complexes on $\mathrm{SiO}_{2}$ did not alter significantly the catalytic activity and selectivity, indicating that the same oxidation mechanism should be operating in both systems. However, immobilization of the catalysts increased their resistance towards oxidative degradation and allowed an efficient recycle (up to five times with comparable results).

Attempts aimed at immobilizing imine-based iron complexes on solid supports have been also carried 
out. $^{[152-155]}$ The easy synthetic procedures for iminebased ligands makes the corresponding complexes preparation extremely suitable for their grafting on solid supports. This topic has been recently reviewed. ${ }^{[119]}$ Preference for allylic oxidation over epoxidation of cyclohexene, ${ }^{[156]}$ or $\mathrm{A} / \mathrm{K}$ ratios close to $1^{[157]}$ have been reported in oxidations mediated by such immobilized catalysts, suggesting a free radical oxidation mechanism.

Sulfur oxidation promoted by imine-based iron complexes has been also investigated with the main aim of achieving an enantioselective transformation. The first report by Bolm and co-workers employed a simple salicyl aldehyde-chiral amino alcohol tridentate imine ligand. The complex was directly assembled in the reaction vessel (see Scheme 18). ${ }^{[138]}$

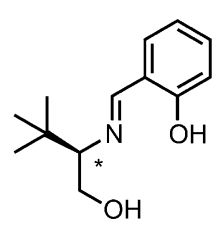

L12

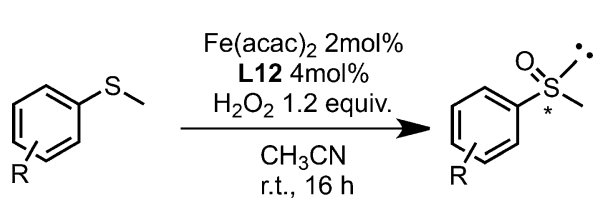

Scheme 18. Bolm's catalytic system for enantioselective sulfoxidation.

Aromatic sulfides were converted to the corresponding sulfoxides with moderate yields (21-44\%) and good enantioselectivities (25-90\% ee). Addition of benzoic acid ( $1 \mathrm{~mol} \%)$ exerted a highly beneficial effect on both yields and enantioselectivity of the transformation $(36-78 \%$ yields and $44-96 \%$ ee $) .{ }^{[159]}$ By changing the electronic properties of the carboxylic acid additive it was found that the electron-rich para-methoxybenzoic acid gave the best results. ${ }^{[159]}$ Further investigations indicated that the active species would be probably coordinated by two chiral ligand units, and that the chirality is directly transferred from such species to the substrates. ${ }^{[160]}$ This catalytic system was later applied to the synthesis of several enantioenriched sulfoxides with relevant biological or pharmacological properties. ${ }^{[10]}$

A related in situ generated catalyst was recently used in enantioselective sulfoxidations with $\mathrm{H}_{2} \mathrm{O}_{2}$ (see Scheme 19), with good yields (up to $86 \%$ ) and ee (75$96 \%){ }^{[161]}$ The ligand loading could be slightly lowered (3 mol\%) with respect to Bolm's system (4 mol\%). Again, the addition of para-methoxybenzoic acid was found to exert a beneficial effect on the enantioselectivity of the transformation.
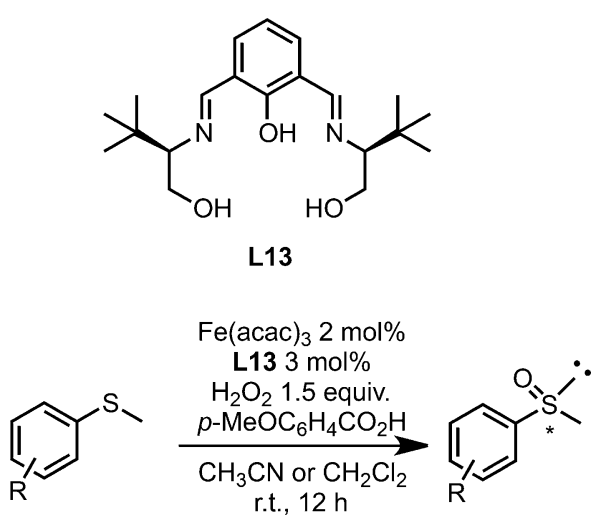

Scheme 19. Catalytic system used in enantioselective sulfide oxidation.

Goldberg investigated imine-based iron complexes as synthetic models of cysteine dioxygenases (CDO). ${ }^{[162]}$ This enzyme catalyzes cysteine side chain oxidation to sulfinic acid $\left(\mathrm{RSO}_{2}{ }^{-}\right)$with $\mathrm{O}_{2}$, and the iron ion in the active site is coordinated by three histidine residues. Tridentate imine $\mathrm{N}_{3}$ ligand $\left({ }^{i \mathrm{Pr}} \mathrm{BIP}\right)$ effectively replicates the $\mathrm{Fe}(\mathrm{II})$ coordination mode in the enzyme (Scheme 20), and the steric hindrance of the isopropyl groups prevents the formation of $\mathrm{O}$ and S-bridged dimers. A thiolate additional ligand lowers the redox potential of the iron complex, enabling reaction with $\mathrm{O}_{2}$, and provides the sulfur which is oxidized. Complex $\left[\left(\mathrm{LN}_{3} \mathrm{~S}\right) \mathrm{Fe}(\mathrm{OTf})\right]$, was indeed found to be highly reactive with atmospheric oxygen, forming the sulfonic acid in $60 \%$ yield (see Scheme 20a). ${ }^{[163]}$ LDI-MS monitoring of the reaction enabled detection of the intermediate sulfenate-iron complex, which is the product of the enzyme-catalyzed reaction, but it was not possible to stop the reaction at this stage. Isotopic analyses indicated that the oxygen atoms inserted on the sulfur center come from atmospheric $\mathrm{O}_{2}$, demonstrating the dioxygenasetype activity of the complex. Iron was essential for the observed reactivity, as the redox inactive $\mathrm{Zn}^{2+}$ complex does not react with $\mathrm{O}_{2}$. The mechanism of $\mathrm{O}_{2}$ activation was also computationally investigated. The calculations supported an intermediate iron-superoxo complex which undergoes sequential $\mathrm{O}-\mathrm{O}$ bond cleavage and $\mathrm{O}$-insertion into the $\mathrm{Fe}-\mathrm{S}$ bond. ${ }^{[164]}$ The ligand may play a non-innocent role in this process, providing the electron required for the superoxide anion formation. Indeed, the one-electron reduced complex was isolated and characterized. ${ }^{[165]}$ Methylation of the thiolate moiety to the methyl sulfide led to the formation of sulfoxide and sulfone in lieu of sulfonic acid. ${ }^{[166]}$ Substitution of triflate counter anion with different pyridines impacted the reactivity only modestly. ${ }^{[165]}$ Later, in 2011, ${ }^{[167]}$ the authors demonstrated that the oxidation does not require the thiolate to be covalently anchored on the ligand. 
(a)

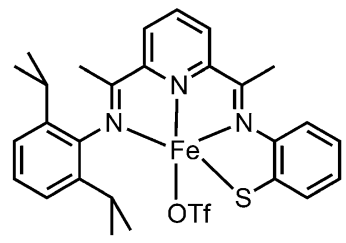

$\left[\left(\mathrm{LN}_{3} \mathrm{~S}\right) \mathrm{Fe}\right] \mathrm{OTs}$

(b)

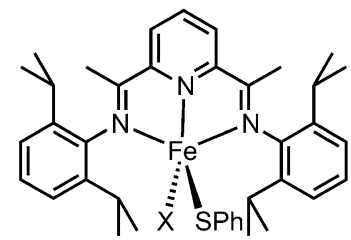

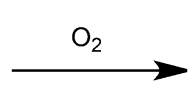

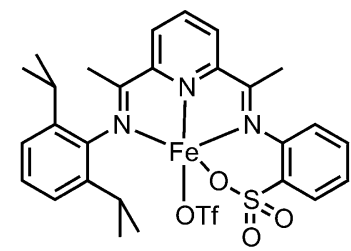<smiles>CCc1cccc(C(C)(C)C)c1N1C(C)=C2C=CC=C(C)N2[PH](OC)(OC)N1c1c(C(C)C)cccc1C(C)C</smiles><smiles>O=C(O)CC(=O)C[W](=O)=O</smiles><smiles>c1ccc(SSc2ccccc2)cc1</smiles>

Scheme 20. Ligand-based S oxidation and Fe oxidation by $\mathrm{O}_{2}$.

Complexes $\quad\left[\left({ }^{i \mathrm{Pr}} \mathrm{BIP}\right) \mathrm{Fe}(\mathrm{SPh})(\mathrm{Cl})\right] \quad$ and $\left[\left({ }^{i \mathrm{Pr}} \mathrm{BIP}\right) \mathrm{Fe}(\mathrm{SPh})(\mathrm{OTf})\right]$ with the thiolate now bound as an additional ligand on the iron ion (see Scheme 20), rapidly reacted with $\mathrm{O}_{2}$. However, they yielded different oxidation products. The chloro complex gave Fe-oxidation, with the formation of the disulfide and an $\left[\left({ }^{i \mathrm{Pr}} \mathrm{BIP}\right) \mathrm{Fe}(\mathrm{IV})(\mathrm{O})(\mathrm{Cl})\right]$ intermediate (I, see Scheme 20b, bottom). Intermediate I was characterized by mass spectrometry/isotopic substitution analysis. This species was able to readily transfer its $\mathrm{O}$-atom to $\mathrm{Ph}_{3} \mathrm{P}$ generating $\mathrm{Ph}_{3} \mathrm{PO}$, and to exchange the oxygen with water. A similar pentadentate $\mathrm{N}_{3} \mathrm{~S}_{2}$ ligand has been previously employed by Nam to generate and characterize an $\mathrm{Fe}(\mathrm{IV})=\mathrm{O}$ intermediate, able to analogously transfer its O-atom. ${ }^{[168]}$ Interestingly, the typical absorption band at $c a .800 \mathrm{~nm}$ of the $\mathrm{Fe}(\mathrm{IV})=\mathrm{O}$ unit is shifted at lower wavelengths with imine-based ligand platforms $(660-690 \mathrm{~nm}) .{ }^{[169]}$ On the other hand, the triflate-complex gave $\mathrm{S}$ oxidation, with the formation of the expected $\mathrm{PhSO}_{3} \mathrm{H}$ (Scheme 20b, top). The difference in reactivity between the two complexes was ascribed to the difference in coordination modes. $\left[\left({ }^{i \mathrm{Pr}} \mathrm{BIP}\right) \mathrm{Fe}(\mathrm{SPh})(\mathrm{Cl})\right]$ displayed the thiolate ligand trans to the available site for $\mathrm{O}_{2}$ binding and activation. Thus, the $\mathrm{PhS}^{-}$ligand cannot interact with the Fe-oxygen moiety. Instead, in the triflate complex, the thiolate ligand is positioned on the $\mathrm{N}_{3}$ BIP plane, in a cis position with respect to the available site, and engages in $\mathrm{S}$ oxidation.

Even previously, in 2006, Kovacs reported the only iron-sulfenate model complex structurally characterized so far. ${ }^{[170]}$ The initial $\left[\mathrm{Fe}(\mathrm{III})(\mathrm{ADIT})_{2}\right]^{+}$is a lowspin octahedral complex in which the iron is coordi- nated by two tridentate $\mathrm{N}_{2} \mathrm{~S}$ ligands, each with a thiolate, an imino and an amino donor (see Scheme 21).

Reaction with an oxaziridine yielded the $\mathrm{S}$ oxidized iron-sulfenate complex. The oxygen atom of $[\mathrm{Fe}(\mathrm{III})(\mathrm{ADIT})(\mathrm{ADIT}-\mathrm{O})]^{+}$could be abstracted by triethylphosphine with formation of $\mathrm{Et}_{3} \mathrm{P}=\mathrm{O}$. In addition, the sulfenate oxygen atom could be reversibly protonated or coordinated by a Lewis acid (namely $\mathrm{ZnCl}_{2}$ ).

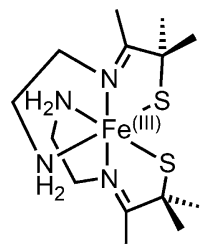

[Fe(III)(ADIT) $\left.)_{2}\right]^{+}$
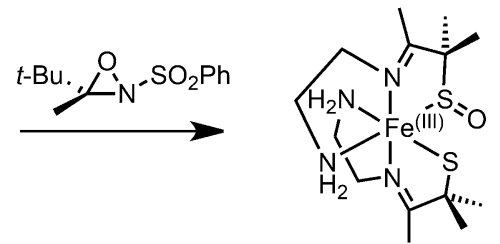

$\left[\mathrm{Fe}(I I I)^{\prime}(\mathrm{ADIT})(\mathrm{ADIT}-\mathrm{O})\right]^{+}$
Scheme 21. Oxidation of $\mathrm{Fe}(\mathrm{III})(\mathrm{ADIT})_{2}$ to the sulfenate complex.

\section{Conclusions}

In conclusion, we have reviewed the results obtained with several imine-based iron complexes as oxidation catalysts. In order to present the topic more clearly, an initial survey on the most used mechanistic tools to distinguish a metal-based oxidation from a radical chain process is presented. Results obtained with salen-Fe and other imine-based iron complexes show a vast array of different catalytic performances in oxidation reactions, ranging from negligible to quantita- 
tive conversion of the substrate. Promising results have been achieved in sulfur oxidation reactions and in $\mathrm{O}_{2}$ activation. However, although thorough mechanistic studies and specific tests have been carried out only in few cases, a consistent part of the catalysts described herein seem to work through a free-radical based oxidation mechanism. For a few complexes, such a Fenton-type catalytic activity was found to be due to ligand degradation and consequent release of the free iron ion in solution. Simple iron salts were indeed found to be effective oxidation catalysts by themselves, but they probably generate oxygen centered radicals which initiate a non-selective radical chain oxidation process. In other cases the presence of more than two labile sites on the iron coordination sphere was proposed to be responsible for such a radical-like oxidation.

However, some of the reported imine-based complexes have the potential to be efficiently used in oxidation catalysis, in particular those featuring high stability under oxidative reaction conditions. When chelating ligands are employed, strong iron complexes are obtained and degradation by hydrolysis is minimized. Such complexes have been found to support high iron oxidation states, and to enable chirality transfer to substrates. A tendency to be oxidatively degraded to the corresponding amides, which usually form less active oxidation catalysts, is often observed. A very significant advantage offered by imine-based iron catalysts is the chance to in situ assemble even elaborate structures from simple starting materials. In this respect, simply self-assembled imine-based iron complexes have been recently reported to catalyze stereospecific $\mathrm{C}-\mathrm{H}$ and $\mathrm{S}$ oxidation with performances comparable to those of several aminopyridine catalysts. For the above reasons, we believe that iminebased ligands can be competitively used in the design of oxidation catalysts.

\section{Acknowledgements}

The authors thank Prof. Miquel Costas for the long and stimulating discussions.

\section{References}

[1] M. C. White, Science 2012, 335, 807-809.

[2] T. Newhouse, P. S. Baran, Angew. Chem. 2011, 123, 3422-3435; Angew. Chem. Int. Ed. 2011, 50, 33623374.

[3] G. Dyker, Handbook of $\mathrm{C}-\mathrm{H}$ Transformations, VCH, Weinheim, Germany, 2005.

[4] K. Godula, D. Sames, Science 2006, 312, 67-73.

[5] J. A. Labinger, J. E. Bercaw, Nature 2002, 417, 507514.
[6] Y. Zhu, Q. Wang, R. G. Cornwall, Y. Shi, Chem. Rev. 2014, 114, 8199-8256.

[7] R. L. Davis, J. Stiller, T. Naicker, H. Jiang, K. A. Jørgensen, Angew. Chem. 2014, 126, 7534-7556; Angew. Chem. Int. Ed. 2014, 53, 7406-7426.

[8] I. Fernández, N. Khiar, Chem. Rev. 2003, 103, 36513705.

[9] M. C. Carreno, Chem. Rev. 1995, 95, 1717-1760.

[10] J. Legros, J. R. Dehli, C. Bolm, Adv. Synth. Catal. 2005, 347, 19-31.

[11] M. S. Chen, M. C. White, Science 2007, 318, 783-787.

[12] M. S. Chen, M. C. White, Science 2010, 327, 566-571.

[13] K. Chen, L. Que Jr, J. Am. Chem. Soc. 2001, 123, 6327-6337.

[14] L. Gómez, I. Garcia-Bosch, A. Company, J. BenetBuchholz, A. Polo, X. Sala, X. Ribas, M. Costas, Angew. Chem. 2009, 121, 5830-5833; Angew. Chem. Int. Ed. 2009, 48, 5720-5723.

[15] M. Canta, D. Font, L. Gómez, X. Ribas, M. Costas, Adv. Synth. Catal. 2014, 356, 818-830.

[16] Y. Hitomi, K. Arakawa, T. Funabiki, M. Kodera, Angew. Chem. 2012, 124, 3504-3508; Angew. Chem. Int. Ed. 2012, 51, 3448-3452.

[17] Y. He, J. D. Gorden, C. R. Goldsmith, Inorg. Chem. 2011, 50, 12651-12660.

[18] A. Company, L. Gómez, M. Güell, X. Ribas, J. M. Luis, L. Que Jr, M. Costas, J. Am. Chem. Soc. 2007, 129, 15766-15767.

[19] A. Thibon, V. Jollet, C. Ribal, K. Sénéchal-David, L. Billon, A. B. Sorokin, F. Banse, Chem. Eur. J. 2012, 18, 2715-2724.

[20] A. C. Lindhorst, S. Haslinger, F. E. Kühn, Chem. Commun. 2015, 51, 17193-17212.

[21] G. Olivo, O. Lanzalunga, L. Mandolini, S. Di Stefano, J. Org. Chem. 2013, 78, 11508-11512.

[22] D. Clemente-Tejeda, A. López-Moreno, F. A. Bermejo, Tetrahedron 2013, 69, 2977-2986.

[23] E. P. Talsi, K. P. Bryliakov, Coord. Chem. Rev. 2012, 256, 1418-1434.

[24] O. Cussó, X. Ribas, J. Lloret-Fillol, M. Costas, J. Am. Chem. Soc. 2013, 135, 14871-14878.

[25] O. Cussó, X. Ribas, M. Costas, Chem. Commun. 2015, 51, 14285-14298.

[26] O. Y. Lyakin, R. V. Ottenbacher, K. P. Bryliakov, E. P. Talsi, ACS Catal. 2012, 2, 1196-1202.

[27] R. V. Ottenbacher, D. G. Samsonenko, E. P. Talsi, K. P. Bryliakov, ACS Catal. 2014, 4, 1599-1606.

[28] W. Dai, G. Li, B. Chen, L. Wang, S. Gao, Org. Lett. 2015, 17, 904-907.

[29] A. Fingerhut, O. V. Serdyuk, S. B. Tsogoeva, Green Chem. 2015, 17, 2042-2058.

[30] G. Anilkumar, B. Bitterlich, F. G. Gelalcha, M. K. Tse, M. Beller, Chem. Commun. 2007, 289-291.

[31] F. G. Gelalcha, Adv. Synth. Catal. 2014, 356, 261-299.

[32] K. Suzuki, P. D. Oldenburg, L. Que Jr, Angew. Chem. 2008, 120, 1913-1915; Angew. Chem. Int. Ed. 2008, 47, 1887-1889.

[33] I. Prat, D. Font, A. Company, K. Junge, X. Ribas, M. Beller, M. Costas, Adv. Synth. Catal. 2013, 355, 947956. 
[34] P. Spannring, I. Prat, M. Costas, M. Lutz, P. C. A. Bruijnincx, B. M. Weckhuysen, R. J. M. Klein Gebbink, Catal. Sci. Technol. 2014, 4, 708-716.

[35] S. Chatterjee, T. K. Paine, Angew. Chem. 2015, 127, 9470-9474; Angew. Chem. Int. Ed. 2015, 54, 93389342.

[36] T. W.-S. Chow, E. L.-M. Wong, Z. Guo, Y. Liu, J.-S. Huang, C.-M. Che, J. Am. Chem. Soc. 2010, 132, 13229-13239.

[37] K. Chen, M. Costas, J. Kim, A. K. Tipton, L. Que Jr, J. Am. Chem. Soc. 2002, 124, 3026-3035.

[38] P. D. Oldenburg, A. A. Shteinman, L. Que Jr, J. Am. Chem. Soc. 2005, 127, 15672-15673.

[39] W. N. Oloo, L. Que Jr, Acc. Chem. Res. 2015, 48, 2612-2621.

[40] J. Park, Y. Morimoto, Y.-M. Lee, W. Nam, S. Fukuzumi, Inorg. Chem. 2014, 53, 3618-3628.

[41] I. Prat, A. Company, V. Postils, X. Ribas, L. Que Jr, J. M. Luis, M. Costas, Chem. Eur. J. 2013, 19, 67246738.

[42] Z. Codola, J. Lloret-fillol, M. Costas, Aminopyridine Iron and Manganese Complexes as Molecular Catalysts for Challenging Oxidative Transformations, John Wiley \& Sons, 2014.

[43] P. E. Gormisky, M. C. White, J. Am. Chem. Soc. 2013, 135, 14052-14055.

[44] H. Lu, X. P. Zhang, Chem. Soc. Rev. 2011, 40, 18991909.

[45] C.-M. Che, V. K. Lo, C.-Y. Zhou, J.-S. Huang, Chem. Soc. Rev. 2011, 40, 1950-1975.

[46] B. Meunier, S. P. de Visser, S. Shaik, Chem. Rev. 2004 104, 3947-3980.

[47] B. Meunier, Chem. Rev. 1992, 92, 1411-1456.

[48] M. Ciaccia, R. Cacciapaglia, P. Mencarelli, L. Mandolini, S. Di Stefano, Chem. Sci. 2013, 4, 2253-2261.

[49] M. Ciaccia, S. Di Stefano, Org. Biomol. Chem. 2015, 13, 646-654.

[50] M. Ciaccia, S. Pilati, R. Cacciapaglia, L. Mandolini, S. Di Stefano, Org. Biomol. Chem. 2014, 12, 3282-3287.

[51] W. N. Oloo, L. Que Jr, Hydrocarbon Oxidations Catalyzed by Bio-Inspired Nonheme Iron and Copper Catalysts, Elsevier Ltd., 2013.

[52] K. P. Bryliakov, E. P. Talsi, Coord. Chem. Rev. 2014, 276, 73-96.

[53] D. T. Sawyer, A. Sobkowiak, T. Matsuhita, Acc. Chem. Res. 1996, 29, 409-416.

[54] J. K. Kochi, (Ed.), Free Radicals, Wiley, 1973.

[55] E. Baciocchi, O. Lanzalunga, B. Pirozzi, Tetrahedron 1997, 53, 12287-12298.

[56] Y. Goto, T. Matsui, S. I. Ozaki, Y. Watanabe, S. Fukuzumi, J. Am. Chem. Soc. 1999, 121, 9497-9502.

[57] W. Nam, Y.-M. Lee, S. Fukuzumi, Acc. Chem. Res. 2014, 47, 1146-1154.

[58] J. Park, Y. Morimoto, Y. M. Lee, W. Nam, S. Fukuzumi, J. Am. Chem. Soc. 2011, 133, 5236-5239.

[59] F. Gozzo, J. Mol. Catal. A: Chem. 2001, 171, 1-22.

[60] J. Groves, P. Viski, J. Org. Chem. 1990, 55, 3628-3634.

[61] Some of these tools have been previously discussed in M. Costas, K. Chen, L. Que Jr, Coord. Chem. Rev. 2000, 200-202, 517-544.

[62] P. A. MacFaul, K. U. Ingold， D. D. M. Wayner， L. Que Jr, J. Am. Chem. Soc. 1997, 119, 10594-10598.
[63] G. A. Russell, J. Am. Chem. Soc. 1957, 79, 3871-3877.

[64] J. Kim, R. G. Harrison, C. Kim, L. Que Jr, J. Am. Chem. Soc. 1996, 118, 4373-4379.

[65] K. Chen, L. Que Jr, Chem. Commun. 1999, 13751376.

[66] S. K. Mandal, L. Que Jr, Inorg. Chem. 1997, 36, 5424 5425.

[67] G. V. Buxton, C. L. Greenstock, W. P. Helman, A. B. Ross, J. Phys. Chem. Ref. Data 1988, 17, 513-886.

[68] A. Company, J. Lloret-Fillol, M. Costas, Small Molecule Models for Nonporphyrinic Iron and Manganese Oxygenases, Elsevier Ltd., 2013.

[69] A. Company, L. Gómez, X. Fontrodona, X. Ribas, M. Costas, Chem. Eur. J. 2008, 14, 5727-5731.

[70] As stated by Hartwig, the selectivity-determining step "refers to an irreversible step that controls which of two (or more) possible products are formed in a reaction with multiple competing pathways. Although the selectivity-determining step can also be the rate-determining step, the selectivity-determining step does not need to be the rate-determining step." See: E. M. Simmons, J. F. Hartwig, Angew. Chem. 2012, 124, 31203126; Angew. Chem. Int. Ed. 2012, 51, 3066-3072.

[71] I. W. C. E. Arends, K. U. Ingold, D. D. M. Wayner, J. Am. Chem. Soc. 1995, 117, 4710-4711.

[72] D. H. R. Barton, D. Doller, Acc. Chem. Res. 1992, 25 , 504-512.

[73] G. B. Shul'pin, J. Mol. Catal. A: Chem. 2002, 189, 3966.

[74] G. B. Shul'pin, G. V. Nizova, React. Kinet. Catal. Lett. 1992, 48, 333-338.

[75] G. B. Shul'pin, A. N. Druzhinina, React. Kinet. Catal. Lett. 1992, 47, 207-211.

[76] E. Baciocchi, F. D'Acunzo, C. Galli, O. Lanzalunga, J. Chem. Soc. Perkin Trans. 2 1996, 133-140.

[77] D. H. R. Barton, A. H. Beck, D. K. Taylor, Tetrahedron 1995, 51, 5245-5254.

[78] P. J. Krusic, P. Meakin, J. P. Jesson, J. Phys. Chem. 1971, 75, 3438-3453.

[79] S. Miyajima, O. Simamura, Bull. Chem. Soc. Jpn. 1975, 48, 526-530.

[80] J. Bernadou, B. Meunier, Chem. Commun. 1998, 2167-2173.

[81] M. J. Davies, Biochim. Biophys. Acta 1988, 964, 28-35.

[82] F. G. Gelalcha, G. Anilkumar, M. K. Tse, A. Brückner, M. Beller, Chem. Eur. J. 2008, 14, 7687-7698.

[83] W. N. Oloo, Y. Feng, S. Iyer, S. Parmelee, G. Xue, L. Que Jr, New J. Chem. 2013, 37, 3411-3415.

[84] J. T. Groves, J. Chem. Educ. 1985, 62, 928-931.

[85] K. C. C. Gupta, A. K. Sutar, Coord. Chem. Rev. 2008, $252,1420-1450$.

[86] J. Collins, Acc. Chem. Res. 1994, 27, 279-285.

[87] J. England, C. R. Davies, M. Banaru, A. J. P. White, G. J. P. Britovsek, Adv. Synth. Catal. 2008, 350, 883897.

[88] M. Grau, A. Kyriacou, F. Cabedo Martinez, I. M. de Wispelaere, A. J. P. White, G. J. P. Britovsek, Dalton Trans. 2014, 43, 17108-17119.

[89] D. Pijper, P. Saisaha, J. W. de Boer, R. Hoen, C. Smit, A. Meetsma, R. Hage, R. P. van Summeren, P. L. Alsters, B. L. Feringa, W. R. Browne, Dalton Trans. 2010, 39, 10375-10381. 
[90] K. P. Bryliakov, E. P. Talsi, Angew. Chem. 2004, 116, 5340-5342; Angew. Chem. Int. Ed. 2004, 43, 52285230.

[91] P. G. Cozzi, Chem. Soc. Rev. 2004, 33, 410-421.

[92] K. P. Bryliakov, E. P. Talsi, Chem. Eur. J. 2007, 13, 8045-8050.

[93] C. Baleizão, H. Garcia, Chem. Rev. 2006, 106, $3987-$ 4043.

[94] V. K. Sivasubramanian, M. Ganesan, S. Rajagopal, R. Ramaraj, J. Org. Chem. 2002, 67, 1506-1514.

[95] E. M. McGarrigle, D. G. Gilheany, Chem. Rev. 2005, $105,1563-1602$.

[96] N. S. Venkataramanan, G. Kuppuraj, S. Rajagopal, Coord. Chem. Rev. 2005, 249, 1249-1268.

[97] T. Kurahashi, Y. Kobayashi, S. Nagatomo, T. Tosha, T. Kitagawa, H. Fujii, Inorg. Chem. 2005, 44, 8156-8166.

[98] T. Chattopadhyay, D. Das, J. Coord. Chem. 2009, 62, 845-853.

[99] A. M. I. Jayaseeli, S. Rajagopal, J. Mol. Catal. A: Chem. 2009, 309, 103-110.

[100] M. Bagherzadeh, M. Zare, J. Sulfur Chem. 2011, 32, 335-343

[101] Z. Yang, C. Zhu, Z. Li, Y. Liu, G. Liu, Y. Cui, Chem. Commun. 2014, 50, 8775-8778.

[102] S. Liao, B. List, Adv. Synth. Catal. 2012, 354, 23632367.

[103] C. Mukherjee, A. Stammler, H. Bögge, T. Glaser, Chem. Eur. J. 2010, 16, 10137-10149.

[104] A. M. Aslam, S. Rajagopal, M. Vairamani, M. Ravikumar, Transit. Met. Chem. 2011, 36, 751-759.

[105] G. Baráth, J. Kaizer, J. S. Pap, G. Speier, N. El Bakkali-Taheri, A. J. Simaan, Chem. Commun. 2010, 46, 7391-7393.

[106] D. P. Barbosa Souza, A. T. Fricks, H. M. Alvarez, G. C. Salomao, M. H. Neves Olsen, L. C. Filho, C. Fernandes, O. A. C. Antunes, Catal. Commun. 2007, 8, 1041-1046.

[107] X. H. Lu, Q. H. Xia, H. J. Zhan, H. X. Yuan, C. P. Ye, K. X. Su, G. Xu, J. Mol. Catal. A: Chem. 2006, 250, 62-69.

[108] A. N. Biswas, P. Das, S. K. Kandar, A. Agarwala, D. Bandyopadhyay, P. Bandyopadhyay, Catal. Commun. 2009, 10, 708-711.

[109] A. Dhakshinamoorthy, K. Pitchumani, Tetrahedron 2006, 62, 9911-9918.

[110] S. Góger, D. Bogáth, G. Baráth, A. J. Simaan, G. Speier, J. Kaizer, J. Inorg. Biochem. 2013, 123, 46-52.

[111] G. C. Salomão, M. H. N. Olsen, V. Drago, C. Fernandes, L. Cardozo Filho, O. a C. Antunes, Catal. Commun. 2007, 8, 69-72.

[112] R. Mayilmurugan, H. Stoeckli-Evans, E. Suresh, M. Palaniandavar, Dalton Trans. 2009, 5101-5114.

[113] A. R. Silva, T. Mourão, J. Rocha, Catal. Today 2013, $203,81-86$.

[114] I. Tabushi, T. Nakajima, K. Seto, Tetrahedron Lett. 1980, 21, 2565-2568.

[115] E. Kadwa, M. D. Bala, H. B. Friedrich, Appl. Clay Sci. 2014, 95, 340-347.

[116] R. J. Corrêa， G. C. Salomão, M. H. N. Olsen, L. C. Filho, V. Drago, C. Fernandes, O. A. C. Antunes, Appl. Catal. A: Gen. 2008, 336, 35-39.
[117] V. Mirkhani, M. Moghadam, S. Tangestaninejad, I. Mohammadpoor-Baltork, N. Rasouli, Catal. Commun. 2008, 9, 2171-2174.

[118] F. Farzaneh, M. Poorkhosravani, M. Ghandi, J. Mol. Catal. A: Chem. 2009, 308, 108-113.

[119] K. C. Gupta, A. Kumar Sutar, C.-C. Lin, Coord. Chem. Rev. 2009, 253, 1926-1946.

[120] S. Khare, R. Chokhare, J. Mol. Catal. A: Chem. 2011, 344, 83-92.

[121] S. Bhattacharjee, T. J. Dines, J. A. Anderson, J. Phys. Chem. C 2008, 112, 14124-14130.

[122] B. Fan, H. Li, W. Fan, C. Jin, R. Li, Appl. Catal. A: Gen. 2008, 340, 67-75.

[123] R. R. Fernandes, M. V. Kirillova, J. A. L. da Silva J. J. R. Fraústo da Silva, A. J. L. Pombeiro, Appl. Catal. A: Gen. 2009, 353, 107-112.

[124] G. B. Shul'pin, Dalton Trans. 2013, 42, 12794-12818.

[125] G. J. P. Britovsek, J. England, A. J. P. White, Inorg. Chem. 2005, 44, 8125-8134.

[126] J. England, G. J. P. Britovsek, N. Rabadia, A. J. P. White, Inorg. Chem. 2007, 46, 3752-3767.

[127] G. J. P. Britovsek, J. England, A. J. P. White, Dalton Trans. 2006, 1399-1408.

[128] J. England, R. Gondhia, L. Bigorra-Lopez, A. R. Petersen, A. J. P. White, G. J. P. Britovsek, Dalton Trans. 2009, 5319-5334.

[129] G. J. P. Britovsek, J. England, S. K. Spitzmesser, A. J. P. White, D. J. Williams, Dalton Trans. 2005, 945955.

[130] S. Tanase, J. Reedijk, R. Hage, G. Rothenberg, Top. Catal. 2010, 53, 1039-1044.

[131] Tridentate iron complexes have been usually found to cleave the $\mathrm{O}-\mathrm{O}$ bond homolytically. (see refs. ${ }^{[125,128]}$ ). In addition, tridentate ligands allow for a less efficient control over the nuclearity of the species in solution.

[132] M. Costas, L. Que Jr, Angew. Chem. 2002, 114, 22832285; Angew. Chem. Int. Ed. 2002, 41, 2179-2181.

[133] J. Tang, P. Gamez, J. Reedijk, Dalton Trans. 2007, 4644-4646.

[134] B. Retcher, J. S. Costa, J. Tang, R. Hage, P. Gamez, J. Reedijk, J. Mol. Catal. A: Chem. 2008, 286, 1-5.

[135] A. Pevec, O. Roubeau, S. Dehnen, S. Nayak, P. Gamez, B. Kozlevc, J. Reedijk, Polyhedron 2010, 29 , 2291-2296.

[136] M. N. Kopylovich, T. C. O. MacLeod, M. Haukka, G. I. Amanullayeva, K. T. Mahmudov, A. J. L. Pombeiro, J. Inorg. Biochem. 2012, 115, 72-77.

[137] D. S. Nesterov, E. N. Chygorin, V. N. Kokozay, V. V. Bon, Y. N. Kozlov, L. S. Shul, J. Jezierska, A. Ozarowski, A. J. L. Pombeiro, G. B. Shul'pin, Inorg. Chem. 2012, 51, 9110-9122.

[138] D. S. Nesterov, O. V. Nesterova, M. F. C. Guedes da Silva, A. J. L. Pombeiro, Catal. Sci. Technol. 2015, 5, 1801-1812.

[139] P. Shejwalkar, N. P. Rath, E. B. Bauer, Dalton Trans. 2011, 40, 7617-7631.

[140] M. Lenze, E. T. Martin, N. P. Rath, E. B. Bauer, Chempluschem 2013, 78, 101-116.

[141] O. Martínez-Ferraté, G. J. P. Britovsek, C. Claver, P. W. N. M. van Leeuwen, Inorg. Chim. Acta 2015, 431, $156-160$. 
[142] M. K. Coggins, S. Toledo, J. A. Kovacs, Inorg. Chem. 2013, 52, 13325-13331.

[143] G. Olivo, G. Arancio, L. Mandolini, O. Lanzalunga, S. Di Stefano, Catal. Sci. Technol. 2014, 4, 2900-2904.

[144] In 1,2-cis-dimethyl-cyclohexane oxidation the O-atom comes almost quantitatively from $\mathrm{H}_{2} \mathrm{O}_{2}(96 \%)$. However, when stronger $\mathrm{C}-\mathrm{H}$ bonds are considered (namely those of cyclohexane), lower incorporation was observed $(80 \%)$. Since no O-atom incorporation from water was found, the complementary amount should derive from atmospheric $\mathrm{O}_{2}$ through a competitive, yet minor radical chain oxidation mechanism.

[145] G. Olivo, M. Nardi, D. Vìdal, A. Barbieri, A. Lapi, L. Gómez, O. Lanzalunga, M. Costas, S. Di Stefano, Inorg. Chem. 2015, 54, 10141-10152.

$\left.[146]\left[(\mathbf{L 8})_{2} \mathrm{Fe}\right](\mathrm{OTf})_{2}\right]$ has been demonstrated to be the actual catalyst, since the catalytic performances of the in situ prepared complex are coincident, within the experimental error, to those of the pre-synthesized and isolated complex.

[147] A. Gonzalez-de-Castro, C. M. Robertson, J. Xiao, J. Am. Chem. Soc. 2014, 136, 8350-8360.

[148] A. Gonzalez-de-Castro, J. Xiao, J. Am. Chem. Soc. 2015, 137, 8206-8218.

[149] G. Bilis, K. C. Christoforidis, Y. Deligiannakis, M. Louloudi, Catal. Today 2010, 157, 101-106.

[150] G. Bilis, P. Stathi, a. Mavrogiorgou, Y. Deligiannakis, M. Louloudi, Appl. Catal. A: Gen. 2014, 470, 376-389.

[151] G. Bilis, M. Louloudi, Bioinorg. Chem. Appl. 2010, DOI 10.1155/2010/861892.

[152] D. Habibi, A. R. Faraji, M. Arshadi, J. L. G. Fierro, J. Mol. Catal. A: Chem. 2013, 372, 90-99.

[153] F. Farzaneh, S. Sohrabi, M. Ghiasi, M. Ghandi, V. Daadmehr, J. Porous Mater. 2013, 20, 267-275.

[154] F. Farzaneh, F. Husseini, L. Hamidipour, M. Ghiasi, $J$. Porous Mater. 2013, 21, 189-196.

[155] S. M. Islam, S. Paul, A. S. Roy, S. Banerjee, K. Ghosh, R. C. Dey, S. C. Santra, Transit. Met. Chem. 2013, 38, 675-682.
[156] T. Akashi, J. Nakazawa, S. Hikichi, J. Mol. Catal. A: Chem. 2013, 371, 42-47.

[157] A. R. Silva, J. Botelho, J. Mol. Catal. A: Chem. 2014, 381, 171-178.

[158] J. Legros, C. Bolm, Angew. Chem. 2003, 115, 56455647; Angew. Chem. Int. Ed. 2003, 42, 5487-5489.

[159] J. Legros, C. Bolm, Angew. Chem. 2004, 116, 43214324; Angew. Chem. Int. Ed. 2004, 43, 4225-4228.

[160] J. Legros, C. Bolm, Chem. Eur. J. 2005, 11, 1086-1092.

[161] P. K. Bera, P. Kumari, S. H. R. Abdi, N. H. Khan, R. I. Kureshy, P. S. Subramanian, H. C. Bajaj, RSC $A d v$. 2014, 4, 61550-61556.

[162] A. C. McQuilken, D. P. Goldberg, Dalton Trans. 2012, 41, 10883-10899.

[163] Y. Jiang, L. R. Widger, G. D. Kasper, M. A. Siegler, D. P. Goldberg, J. Am. Chem. Soc. 2010, 132, 1221412215.

[164] D. Kumar, G. N. Sastry, D. P. Goldberg, S. P. De Visser, J. Phys. Chem. A 2012, 116, 582-591.

[165] L. R. Widger, Y. Jiang, M. A. Siegler, D. Kumar, R. Latifi, S. P. de Visser, G. N. L. Jameson, D. P. Goldberg, Inorg. Chem. 2013, 52, 10467-10480.

[166] L. R. Widger, M. A. Siegler, D. P. Goldberg, Polyhedron 2013, 58, 179-189.

[167] Y. M. Badiei, M. A. Siegler, D. P. Goldberg, J. Am. Chem. Soc. 2011, 133, 1274-1277.

[168] J. Annaraj, S. Kim, M. S. Seo, Y. M. Lee, Y. Kim, S. J. Kim, Y. S. Choi, H. G. Jang, W. Nam, Inorg. Chim. Acta 2009, 362, 1031-1034.

[169] The spectral properties of the amino- and imino-supported $\mathrm{Fe}(\mathrm{IV})=\mathrm{O}$ unit have been thoroughly discussed elsewhere. See: A. R. McDonald, L. Que Jr, Coord. Chem. Rev. 2013, 257, 414-428.

[170] P. Lugo-Mas, A. Dey, L. Xu, S. D. Davin, J. Benedict, W. Kaminsky, K. O. Hodgson, B. Hedman, E. I. Solomon, J. A. Kovacs, J. Am. Chem. Soc. 2006, 128, 11211-11221. 